\title{
Essay
}

\section{Bargaining in the Shadow of Takeover Defenses}

\author{
Guhan Subramanian $^{\dagger}$
}

\section{INTRODUCTION}

For decades, practitioners and academic commentators who believe that target boards should have broad discretion to resist hostile takeover attempts have put forward the "bargaining power hypothesis" to support their view. 'This hypothesis states that a target with strong takeover defenses will extract more in a negotiated acquisition than a target with weaker defenses, because the acquirer's no-deal alternative, to make a hostile bid, is less attractive against a strong-defense target. The hypothesis helped usher in the modern era of takeover defenses: In endorsing the poison pill in Moran $v$. Household International, Inc., the Delaware

$\dagger$ Joseph Flom Assistant Professor of Law and Business, Harvard Law School. I thank George Baker, Lucian Bebchuk, Sanjai Bhagat, Michael Biondi, John Coates, Robert Daines, Jeff Gordon, Andrew Guzman, James Hanks, Marcel Kahan, Louis Kaplow, Russell Korobkin, Reinier Kraakman, Brett MacDonnell, Dan Meltzer, David Millstone, Robert Mnookin, Adam Pritchard, Todd Rakoff, Mark Ramseyer, Edward Rock, Mark Roe, Randall Thomas, Steve Wolitzer, Richard Zeckhauser, and seminar participants at the 2003 American Law and Economics Association annual meeting, Fordham Law School, Harvard Business School, and Harvard Law School for helpful conversations and comments on earlier drafts. I also thank Patricio Delgado, Patricia Martin, Gordon Moodie, Timothy Syrett, and Edward Wei for excellent research assistance. Work on this project was supported by the Harvard Law School summer research fund and the Harvard Negotiation Research Project.

1. For early work putting forth this view, see, for example, Leo Herzel et al., Why Corporate Directors Have a Right To Resist Tender Offers, 61 CHI. BUS. REC. 152, 154 (1979); Martin Lipton, Takeover Bids in the Target's Boardroom, 35 BUS. LAW. 101, 108 (1979); and William H. Steinbrink, Management's Response to the Takeover Attempt, 28 CASE W. RES. L. REV. 882, 893 (1978). For work from the 1980s, see, for example, David D. Haddock et al., Property Rights in Assets and Resistance to Tender Offers, 73 VA. L. REV. 701, 705-06 (1987); Dale Arthur Oesterle, The Negotiation Model of Tender Offer Defenses and the Delaware Supreme Court, 72 CORNELl L. REV. 117, 120-22 (1986); and René M. Stulz, Managerial Control of Voting Rights: Financing Policies and the Market for Corporate Control, 20 J. FIN. ECON. 25 (1988). 
Chancery Court framed the question as a balance between "the unrestricted right of shareholders to participate in nonmanagement sanctioned tender offers" and "the right of a Board of Directors to increase its bargaining powers." 2 The bargaining power hypothesis has been voiced more frequently over the past few years ${ }^{3}$ as other shareholder-focused arguments in favor of takeover defenses, such as protection against "structural coercion" and protection against "substantive coercion," have been rendered less important through federal and state intervention ${ }^{5}$ or challenged by recent empirical evidence. ${ }^{6}$ Yet despite its venerable heritage and recent revitalization, the bargaining power hypothesis has generally been asserted by defense proponents and conceded by defense opponents, ${ }^{7}$ never subjected to a careful theoretical analysis or a comprehensive empirical test.

2. 490 A.2d 1059, 1074 (Del. Ch.), affd, 500 A.2d 1346 (Del. 1985).

3. See, e.g., Stephen M. Bainbridge, Director Primacy in Corporate Takeovers: Preliminary Reflections, 55 STAN. L. REV. 791, 808 (2002); Mark Gordon, Takeover Defenses Work. Is That Such a Bad Thing?, 55 STAN. L. REV. 819, 823 (2002); Marcel Kahan \& Edward Rock, Corporate Constitutionalism: Antitakeover Charter Provisions as Precommitment, 152 U. PA. L. REV. (forthcoming Dec. 2003) (manuscript at 26-27, on file with author); John C. Wilcox, Two Cheers for Staggered Boards, CORP. GOVERNANCE ADVISOR, Nov.-Dec. 2002, at 1, 3-4.

4. See Ronald J. Gilson \& Reinier Kraakman, Delaware's Intermediate Standard for Defensive Tactics: Is There Substance to Proportionality Review?, 44 BUS. LAW. 247, 267 (1989) (coining the term "substantive coercion").

5. See, e.g., Williams Act, Pub. L. No. 90-439, 82 Stat. 454 (1968) (codified as amended at 15 U.S.C. $\S \S 78 \mathrm{~m}(\mathrm{~d})-(\mathrm{e}), 78 \mathrm{n}(\mathrm{d})-(\mathrm{f})(2000))$; CONN. GEN. STAT. $\S \S 33-840$ to -842 (1997) (providing that a fair price, as defined by the statute, must be paid in any control transaction).

6. See Lucian Arye Bebchuk, John C. Coates IV \& Guhan Subramanian, The Powerful Antitakeover Force of Staggered Boards: Theory, Evidence, and Policy, 54 STAN. L. REV. 887 (2002) [hereinafter Bebchuk, Coates \& Subramanian, Powerful Antitakeover Force]; Lucian Arye Bebchuk, John C. Coates IV \& Guhan Subramanian, The Powerful Antitakeover Force of Staggered Boards: Further Findings and a Reply to Symposium Participants, 55 STAN. L. REV. 885 (2002) [hereinafter Bebchuk, Coates \& Subramanian, Reply to Participants]; Lucian Arye Bebchuk, John C. Coates IV \& Guhan Subramanian, The Power of Takeover Defenses (June 2003) (unpublished manuscript, on file with author) [hereinafter Bebchuk, Coates \& Subramanian, The Power of Takeover Defenses].

7. See, e.g., Jonathan R. Macey, Displacing Delaware: Can the Feds Do a Better Job than the States in Regulating Takeovers?, 57 BUS. LAW. 1025, 1039 (2002) (asserting bargaining power as a matter of "common sense intuition"); see also Elazar Berkovitch \& Naveen Khanna, How Target Shareholders Benefit from Value-Reducing Defensive Strategies in Takeovers, 45 J. FIN. 137, 137 (1990) ("Proponents of defensive strategies maintain that they increase the ability of target management to extract a higher price for target shares. Opponents of such strategies ... generally conced[e] this point."). An exception is Professor Lucian Bebchuk, who argues that giving shareholders the right to circumvent the bargaining process and directly accept a bidder's offer does not necessarily reduce management's bargaining power, and that management may use bargaining power to extract private benefits rather than a higher premium for shareholders. See Lucian Arye Bebchuk, The Case Against Board Veto in Corporate Takeovers, 69 U. CHI. L. REV. 973, 1007-09 (2002). I discuss these arguments below. See infra note 96; Section III.E. 
This Essay attempts to fill this gap. I use negotiation-analytic tools to construct a model of bargaining in the "shadow" of takeover defenses. This model identifies the conditions that must exist in order for the bargaining power hypothesis to hold in a particular negotiated acquisition. I demonstrate that the bargaining power hypothesis only applies unambiguously to negotiations in which there is a bilateral monopoly between buyer and seller, no incremental costs to making a hostile bid, symmetric information, and loyal sell-side agents. These conditions suggest that the bargaining power hypothesis is only true in a subset of all deals, contrary to the claim of some defense proponents that the hypothesis applies to all negotiated acquisitions.

I confirm the features of this model with evidence from practitioner interviews. It is interesting to note that while the bargaining power hypothesis lies squarely at the intersection of law and business-namely, legal rules on takeover defenses influencing the business issue of price-to my knowledge the businesspeople who actually negotiate price have been silent on this question. In order to better understand practitioner views, I interviewed the head or co-head of mergers and acquisitions at ten major New York City investment banks. ${ }^{9}$ Collectively these firms represented either the acquirer or the seller, or both, in seventy-two percent of negotiated acquisitions by number, and ninety-six percent by size, during the 1990 s deal wave. ${ }^{10}$ The evidence compiled from these practitioner interviews is consistent with the theoretical model presented here.

I then test the bargaining power hypothesis against a database of negotiated acquisitions of U.S. public company targets between 1990 and $2002(n=1692)$. If the hypothesis is correct, then premiums should be higher in states that authorize the most potent pills (Georgia, Maryland,

8. Cf. Robert H. Mnookin \& Lewis Kornhauser, Bargaining in the Shadow of the Law: The Case of Divorce, 88 YALE L.J. 950 (1979) (demonstrating how the "shadow of the law" provides endowments that influence outcomes).

9. The interviewees were: Steven Baronoff, Co-Head of Mergers \& Acquisitions, Merrill Lynch \& Co.; Michael J. Biondi, Chairman of Investment Banking, Lazard Frères \& Co.; Douglas Braunstein, Managing Director and Head of Investment Banking Coverage, J.P. Morgan Securities; Louis P. Friedman, Global Head of Mergers \& Acquisitions, Bear, Stearns \& Co.; Robert Kindler, Global Head of Mergers \& Acquisitions, J.P. Morgan Securities; Donald Meltzer, Vice Chairman of Investment Banking and Co-Head of Global Mergers \& Acquisitions, Credit Suisse First Boston; Stephen Munger, Co-Head of Global Mergers \& Acquisitions, Morgan Stanley; James Neissa, Managing Director and Co-Head of Mergers \& Acquisitions, UBS Investment Bank; Gregg Polle, Co-Head of Mergers \& Acquisitions, Citigroup Global Markets; Howard Schiller, Co-Head of Global Industrial and Natural Resources Group (formerly Co-Head of U.S. Mergers \& Acquisitions), Goldman Sachs \& Co.; and Steve Wolitzer, Global Head of Mergers \& Acquisitions, Lehman Brothers. All interviews were conducted in person in New York City, except for one, which was conducted over the phone. All interviews were conducted during the summer of 2003. Interviews lasted between twenty minutes and one hour, with an average length of approximately thirty-five minutes. The interview guide is included in the Appendix to this Essay. I am grateful to all of the interviewees for their time and thoughtful comments.

10. See infra table 1. 
Pennsylvania, and Virginia), and lower in the state that provides the least statutory validation for pills (California), relative to Delaware, which takes a middle ground on the pill question. Consistent with the predictions of my model, however, I find no evidence that premiums are statistically different across these states, either overall or in those subsamples in which bargaining power is most likely to manifest itself. I further test for intrastate differences using the Maryland Unsolicited Takeovers Act of 1999 as the basis for a natural experiment, and also find no empirical support for the bargaining power hypothesis.

These findings have implications for the current antimanagerial, pro-takeover trajectory of Delaware's corporate law jurisprudence in the aftermath of Enron. Proponents of the status quo warn that such doctrinal movements will weaken targets' bargaining power in negotiated acquisitions, which will in turn reduce overall returns for target shareholders. But by unpacking the "black box" of negotiated acquisitions and examining the microlevel underpinnings of the bargaining process, this Essay suggests that a return to the original promise of intermediate scrutiny articulated in Unocal Corp. v. Mesa Petroleum Co. ${ }^{11}$ is unlikely to yield significant negative wealth consequences for target shareholders. Rather, as I and others have argued, ${ }^{12}$ a controlled revitalization of the hostile takeover marketplace can help to improve overall corporate governance, an objective that has become only more important in the post-Enron era.

The remainder of this Essay proceeds as follows. Part II provides relevant background, including the origins of the bargaining power hypothesis and the evidence put forward to support it. Part III constructs a theoretical model of bargaining power in the negotiated acquisition context, beginning with a baseline case in which the bargaining power hypothesis clearly holds, and then adding real-world complexities that make it less plausible in many negotiated acquisitions. In addition, Part III uses evidence from practitioner interviews to illustrate the features of the model. Part IV provides new econometric evidence on the validity of the bargaining power hypothesis. Part $\mathrm{V}$ discusses implications of these findings. Part VI concludes.

11. 493 A.2d 946 (Del. 1985).

12. See, e.g., Bebchuk, Coates \& Subramanian, Reply to Participants, supra note 6; Ronald J. Gilson, Unocal Fifteen Years Later (and What We Can Do About It), 26 DEL. J. CORP. L. 491 (2001); Jeffrey N. Gordon, "Just Say Never?" Poison Pills, Deadhand Pills, and ShareholderAdopted Bylaws: An Essay for Warren Buffett, 19 CARDOZO L. REV. 511 (1997); Guhan Subramanian, A New Takeover Defense Mechanism: Using an Equal Treatment Agreement as an Alternative to the Poison Pill, 23 DEL. J. CORP. L. 375 (1998). 


\section{BACKGROUND}

\section{A. The Modern Arsenal of Takeover Defenses}

Among the takeover defenses that have been developed over the past thirty years, the poison pill is by far the most important defense today. A pill gives target shareholders the right to buy shares of the target (a "flipin" provision), the acquirer (a "flip-over" provision), or both at a substantially discounted price in the event that a single shareholder, or an affiliated group of shareholders, acquires more than a specified percentage of the company's shares (typically between ten and twenty percent). If triggered, the pill provides target shareholders with a sizeable stake in the potential acquirer (flip-over) or dilutes the potential acquirer's stake in the target (flip-in), thus making a hostile takeover considerably more expensive. Since the pill was invented in 1983, it has never been deliberately triggered and is generally understood to be a complete barrier to a direct attack in the form of a conventional tender offer. ${ }^{13}$ Because a pill (as a formal matter) is a dividend of rights to purchase stock, and the board has the exclusive authority to issue dividends, ${ }^{14}$ a pill can be adopted without a shareholder vote, in a matter of hours if necessary. Therefore, most companies that do not already have pills in place have "shadow pills" that can be, and usually are, adopted after a hostile bid is launched. ${ }^{15}$

While their basic mechanics are generally the same, pills vary in their potency due to important differences in the background state corporate law. Delaware, which is home to approximately fifty percent of U.S. public companies, ${ }^{16}$ originally adopted a middle ground position on the pill. In

13. The closest anyone has come to a deliberate triggering of a poison pill was Sir James Goldsmith's successful bid for Crown Zellerbach in 1985. Goldsmith crossed the twenty percent threshold that caused the rights to be distributed to Crown shareholders, but he avoided the negative effects of the pill by withdrawing his tender offer, acquiring majority control through open market purchases, and maintaining ownership below the $100 \%$ threshold that would have made the rights exercisable. The parties eventually reached a negotiated settlement that gave Goldsmith control of the company. See Mike Tharp, Goldsmith Wins Fight for Crown Zellerbach Corp., WALL ST. J., July 26, 1985, at A3.

14. See, e.g., DEL. CODE ANN. tit. $8, \S \S 170,173$ (2001).

15. See John C. Coates IV, Takeover Defenses in the Shadow of the Pill: A Critique of the Scientific Evidence, 79 TEX. L. REV. 271, 288 (2000). A target might not put in a so-called "morning after" pill for a number of reasons: because regulatory hurdles already provide a potent defense; because a large block is held by a controlling family or group; because the target has an imminent annual shareholders' meeting, which gives the bidder access to a shareholder referendum anyway; or because the target has already put itself into play and therefore can no longer "Just Say No" to a third-party bidder. See Bebchuk, Coates \& Subramanian, The Power of Takeover Defenses, supra note 6.

16. See Lucian Bebchuk \& Alma Cohen, Firms' Decisions Where To Incorporate, 46 J.L. \& ECON. (forthcoming Oct. 2003) (manuscript at 6, on file with author); Guhan Subramanian, The Influence of Antitakeover Statutes on Incorporation Choice: Evidence on the "Race" Debate and Antitakeover Overreaching, 150 U. PA. L. REV. 1795, 1815 fig.2 (2002). 
1985, the Delaware Supreme Court upheld the pill in Moran v. Household International, Inc., but cautioned that the ability to maintain a pill under Unocal was not absolute:

The ultimate response to an actual takeover bid must be judged by the Directors' actions at that time, and nothing we say here relieves them of their basic fundamental duties to the corporation and its shareholders. Their use of the [poison pill] will be evaluated when and if the issue arises. ${ }^{17}$

In a line of late-1980s cases, the Delaware Chancery Court took up the invitation issued in Moran, invalidated defensive tactics that were not "reasonable in relation to the threat posed" under Unocal, and confirmed that the right to use a pill against a hostile bidder was not absolute. ${ }^{18}$

In the 1990s, however, the Delaware Supreme Court endorsed more potent pills by approving the "Just Say No" defense. In Paramount Communications, Inc. v. Time Inc., the court upheld Time's defensive tactics to preserve a strategic merger between Time and Warner, despite a clearly superior hostile takeover offer for Time from Paramount. ${ }^{19}$ Many commentators interpreted the court's language - that a hostile takeover target could protect its friendly merger "unless there is clearly no basis to sustain the corporate strategy"20 - to mean that a target could "Just Say No" to a hostile bidder by refusing to redeem its poison pill. ${ }^{21}$

Six years later, in Unitrin, Inc. v. American General Corp., the court read Unocal's reasonableness requirement to mean that defensive tactics, provided they are not "coercive" or "preclusive," must fall within a "range of reasonable responses." 22 This restatement of Unocal's proportionality requirement is "operationally similar to the business judgment rule: An action will be sustained if it is attributable to any reasonable judgment." 23 Thus, Unitrin "makes clear how limited an 'enhancement' to the business judgment rule Unocal really is."24 According to then-Chancellor William Allen of the Delaware Chancery Court, a prominent New York City

17. Moran v. Household Int'l, Inc., 500 A.2d 1346, 1357 (Del. 1985) (citations omitted).

18. Grand Metro. Pub. Ltd. v. Pillsbury Co., 558 A.2d 1049 (Del. Ch. 1988) (enjoining a defensive spin-off and mandating pill redemption under Unocal); City Capital Assocs. Ltd. v. Interco Inc., 551 A.2d 787 (Del. Ch. 1988) (enjoining a recapitalization and mandating pill redemption under Unocal); AC Acquisitions Corp. v. Anderson, Clayton \& Co., 519 A.2d 103 (Del. Ch. 1986) (enjoining a defensive recapitalization under Unocal).

19. 571 A.2d 1140 (Del. 1989).

20. Id. at 1154 (emphasis added).

21. See, e.g., James C. Freund \& Rodman Ward, Jr., What's 'In, ' Out' in Takeovers in Wake of Paramount v. Time, NAT'L L.J., Mar. 26, 1990, at 22.

22. 651 A.2d 1361, 1367 (Del. 1995).

23. William T. ALLEN \& REINIER KRAAKMAN, COMMENTARIES AND CASES ON THE LAW OF BUSINESS ORGANIZATION 570 (2003).

24. Id. 
practitioner remarked to him after Unitrin: "So it looks like we're back to business judgment review, aren't we?"25 Thus the limited-use pill identified in Moran was transformed into a more potent "Just Say No" pill.

A standard pill, even a "Just Say No" pill, is still vulnerable to a proxy contest: If a bidder can gain control of the target's board, it can usually redeem the pill and proceed with its tender offer for a majority of the shares. ${ }^{26}$ There are two ways in which a target can nevertheless slow down this kind of collateral attack. First, a staggered board ${ }^{27}$ that cannot be dismantled, ${ }^{28}$ packed, ${ }^{29}$ or otherwise evaded ${ }^{30}$ by a hostile bidder forces the bidder to wait through two annual elections of directors, which can take as long as two years, before it can gain the majority of seats needed to redeem the target's pill. ${ }^{31}$ Approximately fifty percent of U.S. public companies have "effective" (nonevadable) staggered boards (ESBs) ${ }^{32}$ In the mid-1990s, three hostile takeover bids involving Delaware targets with ESBs (Younkers, Wallace Computer, and Circon) all ended in failure for the bidder, even though the bidder had won a first proxy contest to gain one-third of the target's board seats. ${ }^{33}$ Although a target's ability to maintain a pill after losing a first proxy contest is still an open question

25. Conversation with William T. Allen, Nusbaum Professor of Law and Business, New York University, in New York, N.Y. (Feb. 20, 2003).

26. See Bebchuk, Coates \& Subramanian, Powerful Antitakeover Force, supra note 6, at 905. The need for board control against a poison pill eliminates the substantive bite of other defensive measures that mattered in the pre-pill era, such as supermajority voting provisions and fair price provisions. See Coates, supra note 15, at 321 (arguing that the pill "completely dominates fair price and supermajority provisions").

27. If a company has a staggered board, directors are grouped into classes (typically three), with each class elected at successive annual meetings. See, e.g., DEL. CODE ANN. tit. 8, § 141(d) (2001) (permitting staggered boards with either two- or three-year terms for directors).

28. If the staggered board is established through the corporation's bylaws (not its charter), then shareholders can usually amend the bylaws and declassify it.

29. If shareholders can set the size of the board and fill the resulting vacancies, they can increase the number of directors and pack the board.

30. If shareholders can remove directors "without cause," they can remove all directors and then petition the court to order a new election of directors.

31. See Bebchuk, Coates \& Subramanian, Powerful Antitakeover Force, supra note 6, at 916.

32. Id. at 895 .

33. Carson Pirie Scott announced its bid for Younkers in October 1994, Moore announced its bid for Wallace Computer in July 1995, and U.S. Surgical announced its bid for Circon in August 1996. In Younkers, the Carson Pirie Scott slate was elected in May 1995; Younkers promptly expanded its board and reseated the incumbent directors who had been voted out. Moore won its proxy contest in December 1995, continued negotiating with Wallace, and eventually withdrew in August 1996. U.S. Surgical won its proxy contest in October 1997 and withdrew in May 1998, when it was itself taken over by Tyco International, which had a policy of not making hostile bids. See Guhan Subramanian, The Disappearing Delaware Effect, 20 J.L. ECON. \& ORG. (forthcoming Apr. 2004) (manuscript at 19, on file with author). 
under Delaware law, ${ }^{34}$ this trilogy may have implicitly endorsed the combination of a poison pill and ESB as a takeover defense. ${ }^{35}$

A second way in which a target board can slow down a bidder's proxy contest challenge is through a "dead hand" or "slow hand" pill. A dead hand (or "continuing director") provision mandates that the pill can only be redeemed by the continuing directors, defined as the directors who were in office when the pill was adopted, or their approved successors. A slow hand (or "delayed redemption") provision prevents any redemption of the pill for a limited period of time (e.g., six months) after a change in board composition. Dead hand and slow hand pills were invalidated by Delaware courts in the late 1990s. ${ }^{36}$ In contrast, dead hand pills have been endorsed in Georgia, ${ }^{37}$ Pennsylvania, ${ }^{38}$ and Virginia, ${ }^{39}$ and slow hand pills have been endorsed in Maryland. ${ }^{40}$ These "high octane" pills are far more potent than the plain vanilla pills that are valid in Delaware; the dead hand pill in particular is generally understood to be a complete defense against a hostile takeover bid.

At the other end of the pill potency spectrum, one state, California, has not validated the flip-in pill, which is the most common version of the pill today. The leading treatise on California corporate law states that such a pill "appears to be violative" of section 203 of the California Corporate Code ${ }^{41}$ which prohibits distinctions among shareholders in the absence of

34. See Leo E. Strine, Jr., The Professorial Bear Hug: The ESB Proposal as a Conscious Effort To Make the Delaware Courts Confront the Basic "Just Say No" Question, 55 STAN. L. REV. 863, 871-73 (2002).

35. See Subramanian, supra note 33 (manuscript at 18-20).

36. See Quickturn Design Sys., Inc. v. Shapiro, 721 A.2d 1281 (Del. 1998) (invalidating the slow hand pill); Carmody v. Toll Bros., 723 A.2d 1180 (Del. Ch. 1998) (invalidating the dead hand pill).

37. See GA. CODE ANN. § 14-2-624(d) (2003); Invacare Corp. v. Healthdyne Techs., Inc., 968 F. Supp. 1578, 1582 (N.D. Ga. 1997).

38. See 15 PA. CONS. STAT. ANN. § 2513 (West 1995); AMP Inc. v. Allied Signal Inc., No. 98-4405, 1998 U.S. Dist. LEXIS 15617, at *34-35 (E.D. Pa. Oct. 8, 1998).

39. See VA. CODE ANN. § 13.1-646(B) (Michie 1999); Chesapeake Corp. v. Shore, 771 A.2d 293, 303 (Del. Ch. 2000) ("As a Virginia corporation, Chesapeake is authorized to - and doeshave in place iron-clad defenses, including a so-called 'dead-hand poison pill' and a staggered board.").

40. See MD. CODE ANN., CORPS. \& ASS'NS § 2-201(c)(2)(ii) (Supp. 2002) (allowing the board to limit the power of future directors to vote for redemption, modification, or termination of a pill for up to 180 days).

41. Harold MarSh, JR. ET aL., MarSh's California Corporation laW $\S 2.05[\mathrm{~F}]$, at 2-50 (4th ed. 2001); see also Peter F. Kerman, Hot Issues in Executive Compensation-Stock Option Grants by Delisted Companies, in TAX LAW AND PRACTICE 465, 481 (PLI Tax Law \& Estate Planning Course, Handbook Series No. J0-004F, 2001) ("California has . . a policy of disfavoring shareholder rights plans or 'poison pills."'); E-mail from Keith Paul Bishop, Commissioner of Corporations in California (1996-1997) (Feb. 5, 2002) (on file with author) ("Because pills discriminate against holders, [section 203] would seem to be a problem."), cited in Subramanian, supra note 16, at 1855 n. 199. 
explicit shareholder authorization. ${ }^{42}$ Even if a California court were to uphold the poison pill at some point in the future, the uncertain status of the pill today indicates that it cannot be used as a bargaining tool in California as effectively as it might be used in other states. ${ }^{43}$

Figure 1 summarizes the varying potency of poison pills described in this Part.

\section{FiguRE 1. PiLl POTENCY SPECTRUM}

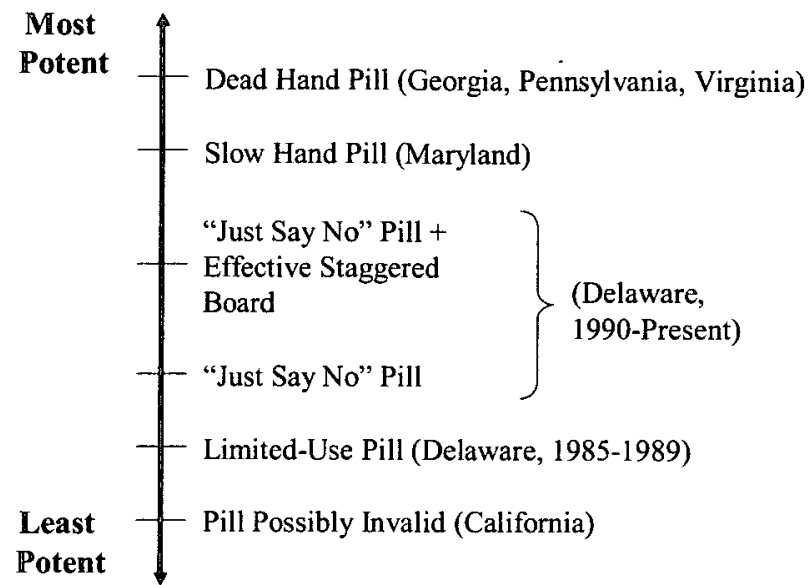

With this background in place, I now describe and assess the arguments that have been put forward to permit stronger takeover defenses. While these are general arguments, applicable to any takeover defense, in the modern (post-pill) era they essentially amount to arguments in favor of more potent poison pills.

\section{B. The Bargaining Power Hypothesis}

Many defense proponents rely on the bargaining power hypothesis to argue that boards should have broad discretion to install and maintain poison pills against hostile bidders. For example, Mark Gordon, a partner at Wachtell, Lipton, Rosen \& Katz, states that takeover defenses should "give targets additional leverage to negotiate a better premium ... in friendly

42. CAL. CORP. CODE $§ 203$ (West 1990) ("Except as specified in the articles or in any shareholders' agreement, no distinction shall exist between classes or series of shares or the holders thereof.").

43. See Stephen Bainbridge, ProfessorBainbridge.com: Delaware's Predictability Redux (Oct. 20, 2003), at http://www.professorbainbridge.com/2003/10/delawares_predi.html ("I've researched [the California pill question] at some length and have been unable to find any significant guidance in either the case law or secondary literature. As far as I can tell, there is no definitive answer.... Relative to California law, Delaware's substantial body of precedent provides a high degree of certainty."). 
transactions ... because the target can more effectively counter the acquiror's implicit threat to 'go hostile' if its various demands are not met." 44 Gordon adds that "even a [very small] benefit ... applied over thousands of friendly deals amounts to a massive net benefit to stockholders of companies that employ an ESB., ${ }^{, 45}$

Gordon states the hypothesis as if it were applicable to all friendly transactions. In a forthcoming University of Pennsylvania Law Review symposium article, Professors Marcel Kahan and Edward Rock similarly state that the bargaining power benefit applies to all friendly deals:

To determine whether boards use their bargaining power to raise acquisition premia, one needs to examine deals where bidder and target reached an agreement-that is, "friendly" deals.... The number of friendly deals dwarfs the number of hostile bids. Thus, even if staggered boards have only a miniscule effect on the target's ability to obtain a better offer in friendly deals, the net effect of such improvement is likely to outweigh the loss from hostile bids blocked by staggered boards. ${ }^{46}$

An obvious implication of the bargaining power hypothesis is that takeover defenses increase overall target shareholder value. Therefore, target boards should have broad discretion to install and maintain takeover defenses, because the costs of bid resistance and possible bid deterrence are outweighed by higher premiums in completed deals. ${ }^{47}$ In Section II.D, I examine the empirical evidence that has been offered thus far to support the bargaining power hypothesis. Before doing so, I briefly review other shareholder-focused arguments that have been put forward to support takeover defenses, and explain why these arguments are less persuasive today than they may have been in the past.

\section{The Decline of Other Arguments}

\section{Preventing Structural Coercion}

In addition to the bargaining power hypothesis, proponents of takeover defenses have put forward two arguments to support the view that such defenses increase shareholder value when a hostile takeover bid has been

44. Gordon, supra note 3, at 823 (emphasis omitted); see also Wilcox, supra note 3, at 4 (arguing that takeover defenses give target boards bargaining power).

45. Gordon, supra note 3 , at 824.

46. Kahan \& Rock, supra note 3 (manuscript at 26-27) (citing Gordon, supra note 3, at 822-24) (footnote omitted).

47. See Bainbridge, supra note 3, at 808; Gordon, supra note 3, at 823-24; Kahan \& Rock, supra note 3 (manuscript at 27). 
launched. The first is that takeover defenses prevent structurally coercive offers, such as two-tier tender offers, "Saturday Night Specials," 48 and cascading tender offers. ${ }^{49}$ The problem with structurally coercive offers is that they may prompt shareholders to tender even if they do not believe that the offer represents fair value for the company. ${ }^{50}$ Thus structural coercion might permit inefficient transfers of corporate control.

The coercion problem is well-understood and well-accepted by practitioners and academic commentators on all sides of the defenses debate. Takeover defenses effectively solve this problem on the sell side by allowing the target board to resist structurally coercive offers. Over the past thirty-five years, however, important federal and state regulation has provided a buy-side solution as well. The Williams Act, passed by Congress in 1968, substantially reduces a bidder's ability to make a structurally coercive offer. ${ }^{51}$ Rule $14 \mathrm{e}-1$, promulgated by the SEC under the authority of the Act, requires that all tender offers stay open for at least twenty business days, thus eliminating the possibility of Saturday Night Specials. ${ }^{52}$ Rule $14 \mathrm{~d}-8$ requires an acquirer to purchase all shares on a pro rata basis if the offer is oversubscribed. ${ }^{53}$ And Rule $14 \mathrm{~d}-10$, the "all-holders rule," requires the acquirer to open its tender offer to all shareholders, and to pay all those who tender the same best price. ${ }^{54}$

At the state level, fair price statutes effectively prohibit coercive offers by setting procedural criteria to determine a fair price in takeover contests, ${ }^{55}$ and control share acquisition statutes indirectly prohibit coercive offers by requiring an (undistorted) shareholder vote in order to make the acquirer's shares votable beyond a certain threshold (typically twenty percent). ${ }^{56}$ Thirty-five states passed a fair price statute, a control share

48. A Saturday Night Special is a tender offer that is open for only a short period of time, typically just a few days, thereby forcing shareholders to decide quickly whether or not to tender. The term was introduced as part of a public relations campaign against Colt Industries' hostile tender offer for Garlock in 1975. See PATRICK A. GAUgHAN, MERGERS, ACQuisitions, AND CORPORATE RESTRUCTURINGS 39-40 (1996).

49. A cascading tender offer provides lower consideration for each successive tranche of shares tendered.

50. See Lucian Arye Bebchuk, The Pressure To Tender: An Analysis and a Proposed Remedy, 12 DEL. J. CORP. L. 911, 922-23 (1987); Lucian Arye Bebchuk, Toward Undistorted Choice and Equal Treatment in Corporate Takeovers, 98 HARV. L. REV. 1693, 1723-25 (1985).

51. See Williams Act, Pub. L. No. 90-439, 82 Stat. 454 (1968) (codified as amended at 15 U.S.C. $\S \S 78 \mathrm{~m}(\mathrm{~d})-(\mathrm{e}), 78 \mathrm{n}(\mathrm{d})-(\mathrm{f})(2000))$.

52. See 17 C.F.R. $\$ 240.14 \mathrm{e}-1$ (2003).

53. See id. $\$ 240.14 \mathrm{~d}-8$.

54. See id. \$240.14d-10.

55. See, e.g., CONN. GEN. STAT. § 33-842(b)(1)-(2) (2003) (requiring an acquirer to pay the highest of the twenty-four month high, market price at the bid announcement date, or a formula that combines these two factors).

56. See, e.g., OHIO REV. CODE ANN. $\S ~ 1701.01,1701.831$ (Anderson 2001) (requiring disinterested shareholder approval for an acquirer to be able to vote its shares beyond a twenty percent threshold). 
acquisition statute, or both during the 1980 s and early 1990s-though, notably, Delaware was not one of them. ${ }^{57}$

As a result of these buy-side reforms, structurally coercive offers became virtually nonexistent by the $1990 \mathrm{~s}^{58}$ The most important place where they continue to appear is in dual consideration offers. ${ }^{59}$ In earlier work I have shown that part-cash, part-stock offers, which are legal under state and federal rules, may become structurally coercive if the stock portion (typically, the back end) does not have the same value as the cash portion. ${ }^{60}$ In fact, an acquirer who raises the front-end cash portion of a takeover bid might make the overall offer more coercive, because the market will take this increase in value out of the back-end stock that is being offered. ${ }^{61}$ Because the Williams Act does not apply to the second step

57. See Subramanian, supra note 16 , at 1827,1828 tbl.3.

58. Patrick McGurn, Special Counsel for Institutional Shareholder Services, made this point humorously in a recent panel discussion at the Harvard Business School:

[Structurally coercive offers] have been used forever as this justification for the "belt, suspenders, duct-tape"-all the various things holding up management's pants at this point.... [I]t's this great monster that's out there, still today, even though we haven't seen one in almost 25 years, that this thing is approaching. It's this two-tiered tender offer that's going to get us all! You guys [takeover defense proponents] have to give up on that. Find a new bad guy at this point.

Brian J. Hall \& Guhan Subramanian, Circon Case Study (A)-(C) teaching note app. at 37 (Harvard Bus. Sch., Case Study No. 5-902-220, 2002).

59. Professor Bebchuk argues that even an all-cash offer to be followed by a back-end freeze-out at the same price is still structurally coercive because shareholders who are frozen out in the back end receive their cash later than shareholders who tender into the front end. See Bebchuk, supra note 7, at 983-85. However, a buyer typically executes its back-end freeze-out immediately after closing its front-end tender offer. For example, in Marathon Oil's all-cash acquisition of Pennaco Energy in 2001, Marathon bought eighty-six percent of Pennaco's shares in a tender offer that closed on February 5, announced a special meeting of shareholders on February 26, and held the special meeting to complete the freeze-out on March 26. See Schedule 14C Information Statement Furnished to the SEC by Pennaco Energy, Inc. (Feb. 26, 2001), http://www.sec.gov/Archives/edgar/data/1069845/000095012901001089/h84457defml4c.txt. In Delaware, the second-step freeze-out can even be executed on the same day as the closing of the first-step tender offer, if the buyer gains ninety percent or more in the first step and thereby qualifies for a short-form merger. See DEL. CODE ANN. tit. 8, $\S 253$ (2001). As a business matter, acquirers generally want to execute the second-step freeze-out as soon as possible in order to gain $100 \%$ of the anticipated economic benefit, to eliminate potential plaintiffs, to delist from the stock exchange, and to deregister under the 1934 Securities and Exchange Act. In addition, failure to move quickly creates significant legal risk due to uncertainty in applying dissenters' appraisal rights. See, e.g., Cede \& Co. v. Technicolor, Inc., 684 A.2d 289, 293-94 (Del. 1996) (discussing whether an acquirer in a 100\% all-cash, two-step transaction should be forced, as the target insisted, to pay its fair share of operational improvements implemented during the twelve-month window between the closing of the first-step tender offer and the second-step freeze-out). Even if shareholders' cost of capital were sufficiently high to make this delay significant (and the offer, by extension, structurally coercive), Professor Bebchuk advocates defensive tactics only until shareholders have had the opportunity to express their view on the transaction through a noncoercive vote, see Bebchuk, supra note 7, at $981-82$, a conclusion that is consistent with the analysis presented here.

60. See Subramanian, supra note 12, at 403-10.

61. See Interview with Morris Kramer, Partner, Skadden, Arps, Slate, Meagher \& Flom, in New York, N.Y. (Mar. 14, 1997) ("Every time you raise the front end, your stock goes down on the back end. That's the problem: you can keep raising the front end, but your back end keeps 
of this kind of bid, ${ }^{62}$ sell-side defenses might be necessary in order to prevent structural coercion. But this argument would only justify defensive measures for offers that are part-cash, part-stock, and only until shareholders have had the opportunity to vote on the transaction (indirectly) through a board election. Proponents of takeover defenses generally do not condition their argument on the type of consideration being offered, nor do they concede that the board should defer to the outcome of a noncoercive shareholder vote. ${ }^{63}$ Thus the structural coercion argument would seem to apply to only a small fraction of the cases in which proponents of takeover defenses would wish to uphold their use.

\section{Preventing Substantive Coercion}

The other argument that has been put forward in support of takeover defenses is that management knows better. ${ }^{64}$ Because target shareholders can sometimes gain more by remaining independent than by selling to the hostile bidder, there is the risk of "substantive coercion," defined by Professors Ronald Gilson and Reinier Kraakman as "the risk that shareholders will mistakenly accept an underpriced offer because they disbelieve management's representations of intrinsic value." ${ }^{\text {"65 }}$ In an influential article published in 1979, Martin Lipton, a founding partner of Wachtell, Lipton, Rosen \& Katz and the inventor of the poison pill, examined a sample of thirty-six hostile takeover targets during the period from 1973 to 1979 that remained independent, and concluded that "shareholders have profited in the overwhelming majority of defeated takeovers." 66 Assuming that a majority of the shareholders would have tendered into these offers, ${ }^{67}$ Lipton's data suggested that management did

going down, and it just becomes more coercive."), cited in Subramanian, supra note 12, at 404 n. 174 .

62. See Richard A. Booth, The Problem with Federal Tender Offer Law, 77 CAL. L. REV. 707, 722 (1989).

63. See, e.g., Bainbridge, supra note 3, at 807-08; Gordon, supra note 3, at 826-27; Lynn A. Stout, Do Antitakeover Defenses Decrease Shareholder Wealth? The Ex Post/Ex Ante Valuation Problem, 55 STAN. L. ReV. 845, 861 (2002).

64. Pennzoil's response to a hostile bid from Union Pacific Resources in June 1997 provides an illustration of this argument in a real-world deal. Despite the fact that sixty-one percent of Pennzoil shareholders had tendered to Union Pacific, Pennzoil's board rejected the bid because it believed that "shareholders will benefit more from its efforts to improve its earnings and future performance than they will from tendering their shares to Union Pacific Resources." Pennzoil Board Spurns Union Pacific Offer, Sues in Federal Court, WALL ST. J., Oct. 15, 1997, at B8; see also Peter Fritsch, Union Pacific Resources May Drop Pennzoil Bid, WALl ST. J., Nov. 12, 1997, at $\mathrm{A} 3$.

65. Gilson \& Kraakman, supra note 4, at 267.

66. Lipton, supra note 1, at 109 (emphasis added).

67. See id. at 113 ("[T] he special dynamics of a tender offer are such that the decision of shareholders is almost always a foregone conclusion - they will tender ...."). 
in fact know better, and, by extension, that the threat of substantive coercion was real.

The idea that remaining independent is beneficial to target shareholders, and therefore that takeover defenses should be permitted to allow this realization of value, gained traction through a series of Delaware Supreme Court cases from the mid-1980s to the mid-1990s. In 1985, the Delaware Supreme Court cited Lipton's "rather impressive study" in upholding Unocal's defensive measures against hostile bidder T. Boone Pickens. ${ }^{68}$ Four years later, the court upheld Time's defensive measures against Paramount's hostile bid based on a perceived threat of "ignorance or a mistaken belief of the strategic benefit which a business combination with Warner might produce." 69 While some read Time itself to endorse substantive coercion, ${ }^{70}$ to the extent that there was any doubt about the issue, the Delaware Supreme Court squarely endorsed the concept six years later, upholding Unitrin's defensive measures against hostile bidder American General:

The record appears to support Unitrin's argument that the Board's justification for adopting the Repurchase Program was its reasonably perceived risk of substantive coercion, i.e., that Unitrin's shareholders might accept American General's inadequate Offer because of "ignorance or mistaken belief" regarding the Board's assessment of the long-term value of Unitrin's stock. ${ }^{71}$

The problem with this line of Delaware cases is that its underlying empirical basis - that target shareholders will achieve better returns if the target remains independent -is on average no longer true (if it ever was) in the modern M\&A marketplace. In 1981, Professor Gilson pointed out several methodological flaws in Lipton's 1979 study, including the lack of any adjustment for market effects or the time value of money. ${ }^{72}$ In recent work, Lucian Bebchuk, John Coates, and I correct these and other deficiencies to examine the outcomes of all hostile takeover contests

68. Unocal Corp. v. Mesa Petroleum Co., 493 A.2d 946, 956 n.11 (Del. 1985).

69. Paramount Communications, Inc. v. Time Inc., 571 A.2d 1140, 1153 (Del. 1989).

70. See, e.g., Strine, supra note 34 , at 875.

71. Unitrin, Inc. v. Am. Gen. Corp., 651 A.2d 1361, 1385 (Del. 1995). In the same year, Moore Corp. v. Wallace Computer Services, Inc. similarly recognized the possibility of substantive coercion, though the case was decided in the federal district court for Delaware and therefore did not generate binding precedent under Delaware corporate law. 907 F. Supp. 1545, 1557 n. 14 (D. Del. 1995).

72. Ronald J. Gilson, A Structural Approach to Corporations: The Case Against Defensive Tactics in Tender Offers, 33 STAN. L. REV. 819, 857-58 (1981); see also Frank H. Easterbrook \& Gregg A. Jarrell, Do Targets Gain from Defeating Tender Offers?, 59 N.Y.U. L. REV. 277 (1984) (surveying existing studies and presenting new evidence to conclude that targets do not gain from defeating tender offers). 
between 1996 and $2002(n=112){ }^{73}$ We track the stock price performance of the forty-one targets from this sample that remained independent and find that shareholders of these targets, on average, received lower buy-andhold abnormal returns than they would have received if the company had been sold to the initial hostile bidder or to a white knight. ${ }^{74}$ Management, at least in the late $1990 \mathrm{~s}$, did not on average know better than their shareholders who wished to accept a hostile offer.

In responding to this work, even ardent supporters of takeover defenses have not questioned our finding that shareholders of targets that remained independent would have achieved higher returns had they sold. ${ }^{75}$ Thus the evolution of the Delaware case law during the 1980s and 1990s, which culminated in the endorsement of substantive coercion by 1995 , seems to be based on an empirical foundation that takeover defense commentators agree is no longer accurate in the modern marketplace. ${ }^{76}$

\section{Evidence in Favor of the Bargaining Power Hypothesis}

To summarize, the problem of Saturday Night Specials, cascading tender offers, and other structurally coercive offers was largely solved by the Williams Act in 1968, subsequent SEC rules, and certain state antitakeover statutes; moreover, to the extent that structural coercion remained, it could only justify a far more limited set of defensive tactics than defense proponents wished to permit. And the argument that takeover defenses allowed targets to remain independent and achieve greater returns for their shareholders has been called into question by recent empirical work, without protest (or even mild objection) from even the most fervent of defense proponents. In the new millennium, a common refuge for supporters of takeover defenses seems to be the bargaining power hypothesis. Not surprisingly, with the decline of other arguments, this

73. See Bebchuk, Coates \& Subramanian, The Power of Takeover Defenses, supra note 6.

74. See id. at 36-37 tbls.5A-5B.

75. See, e.g., Bainbridge, supra note 3, at $807 \mathrm{n} .92$ ("[M]y response to Bebchuk, Coates, and Subramanian's argument that shareholders are injured by the tandem of a staggered board and poison pill can be stated simply as: So what?"); Stout, supra note 63, at 856-57 (acknowledging that the study did "a nice job of undermining the argument that [takeover defenses] increase target shareholders' ex post returns"). Even Lipton seems to have shifted his view on this question. In a recent panel discussion at the Harvard Law School, he stated:

I don't think the results on a zero-sum basis have been favorable for the shareholders of companies at all. You need to take into account the shareholders of the acquiring company and balance that against the obvious profit or benefit that the shareholders of the target company get and, therefore, it's not beneficial for the economy as a whole.

Martin Lipton, Remarks at the Harvard Law School Symposium on Corporate Elections 22 (Oct. 3,2003 ) (transcript on file with author).

76. See Patrick S. McGurn, Classification Cancels Corporate Accountability, 55 STAN. L. REV. 839, 840 (2002) ("Professors Bebchuk, Coates, and Subramanian shatter the shareholdervalue-enhancement mythology that some boards have used to justify their staggered structures in recent years."). 
argument has been stressed more frequently in the past few years. ${ }^{77}$ This Section reviews the evidence that has been put forward to support this theory.

\section{Pill Premium Studies}

Practitioners and academic commentators generally rely on the numerous "pill premium" studies as evidence in favor of the bargaining power hypothesis. Professor Jonathan Macey, for example, states that the pill premium studies "confirm the common sense intuition that, despite the fact that poison pills and other anti-takeover devices are subject to abuse, such devices provide incumbent managers with greater power to negotiate with outside bidders, and this greater negotiating power results in higher premiums for target firm shareholders." ${ }^{, 78}$ Figure 2 summarizes this evidence. $^{79}$

77. See sources cited supra note 3.

78. Macey, supra note 7, at 1039; see also Martin Lipton \& Paul K. Rowe, Pills, Polls and Professors: A Reply to Professor Gilson, 27 DEL. J. CORP. L. 1, 21 (2002) (citing pill premium studies as evidence that pills increase shareholder returns); Mark Gordon, Poor Study Habits, DAILY DEAL, June 20, 2002, at 16 (citing pill premium studies as support for the bargaining power hypothesis).

79. Professors Robert Comment and William Schwert also report results that are consistent with these other studies, but because they do not report univariate statistics their findings are not included in Figure 2. See Robert Comment \& G. William Schwert, Poison or Placebo? Evidence on the Deterrence and Wealth Effects of Modern Antitakeover Measures, 39 J. FN. ECON. 3 (1995). 


\section{Figure 2. Pill Premium Study Results ${ }^{80}$}

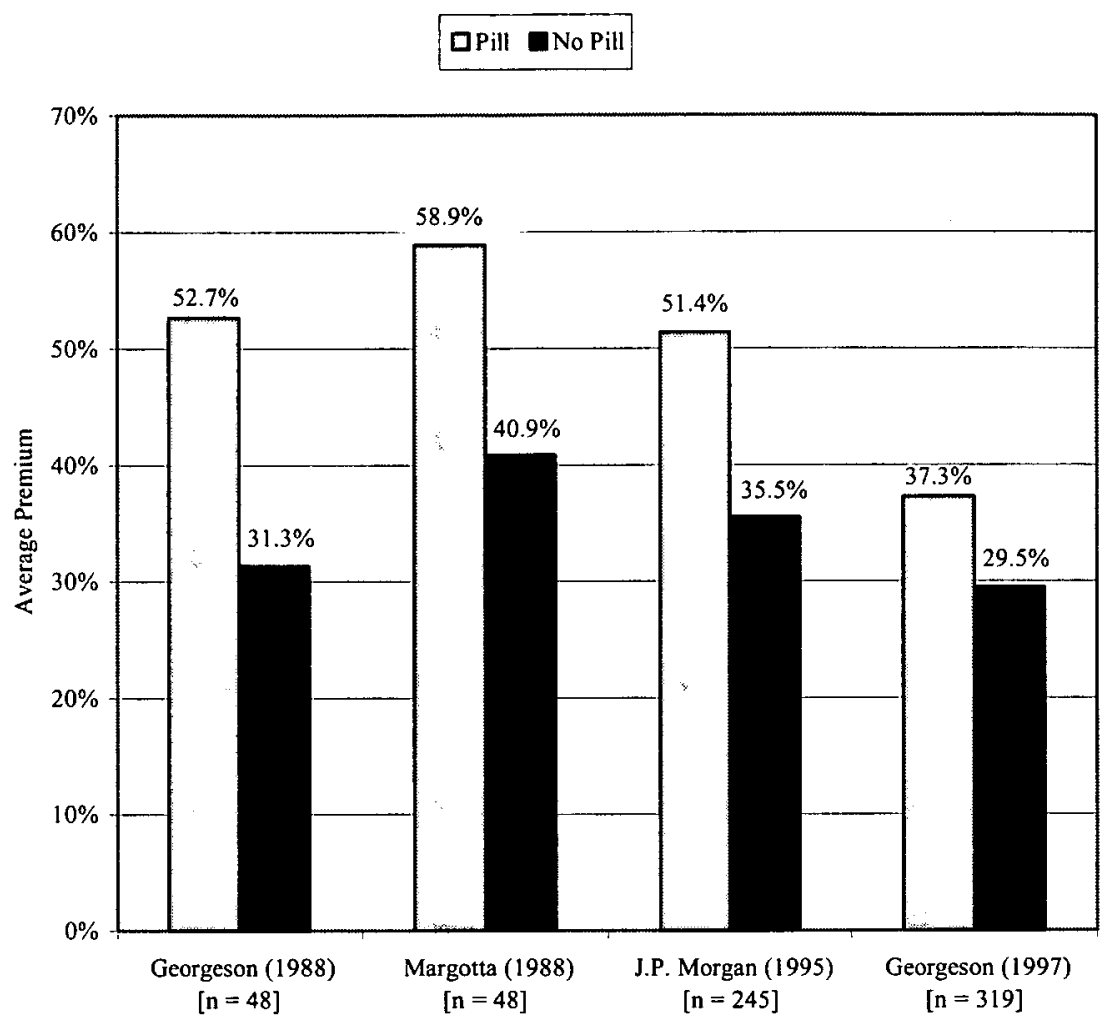

Although the sample sizes, methodologies, and time frames differ, Figure 2 shows that the results are quite consistent across studies: Targets with pills achieve higher premiums than targets without pills. A basic flaw in all of the pill studies, however, arises from the fact that virtually all targets that do not have pills have the option to put them in at any point during the takeover negotiation; thus, friendly acquisitions are generally negotiated in the "shadow" of the poison pill. ${ }^{81}$ Because acquirers will know this fact as well, it is unclear how to interpret the results from the pill

80. The studies in this Figure, in the order in which they appear, are: News Release, Georgeson \& Company Inc., Companies Protected by Poison Pills Received Premiums 69\% Higher in Takeover Contests than Companies Without Pills fig.3 (Mar. 31, 1988) (on file with author); Donald G. Margotta, Takeover Premiums: With and Without Shareholder Rights Plans 13 fig.1 (1988) (unpublished manuscript, on file with author); RICK ESCHERICH \& IAN CAMERON, J.P. MORGAN, POISON PILlS AND ACQUISITION PREMIUMS 1 (1995); GEORGESON

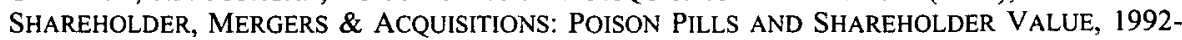
1996, at 2 (1997), http://www.georgesonshareholder.com/pdf/M\&Apoisonpill.pdf.

81. See Coates, supra note 15, at 277. 
premium studies. Practitioners, ${ }^{82}$ judges, ${ }^{83}$ and corporate law academics ${ }^{84}$ (other than those who rely on the pill studies) have generally accepted this point-that the results from the pill premium studies are ambiguous at best, and perhaps meaningless. Rather than a "bargaining power" interpretation, Professor Coates puts forward several more plausible explanations: Firms may be more likely to adopt pills if they are difficult to value without private information, suggesting that due diligence may reveal more information and therefore may lead to higher premiums; firms may be more likely to adopt pills in consolidating industries, in which competition among industry players may drive bid prices upward; or pills may be adopted by poorly performing companies, which can then extract higher premiums from acquirers because the opportunity for improvement is greater. $^{85}$

Professors Kahan and Rock nevertheless attempt to salvage the pill premium studies as support for the bargaining power hypothesis with the argument that "the adoption of a pill signals that management is ready to use this power to extract a higher premium (at the risk of defeating a bid)." ${ }^{\prime 86}$ Others who have examined the issue more closely, however, find no evidence to support this view. ${ }^{87}$ M\&A practitioners generally reject this

82. See, e.g., R. Franklin Balotti \& J. Travis Laster, Professor Coates Is Right. Now Please Study Stockholder Voting., 54 U. MIAMI L. REV. 819 (2000).

83. See, e.g., Jack B. Jacobs, Comments on Contestability, 54 U. MIAMI L. REV. 847 (2000). Jacobs, then a Delaware Vice Chancellor and now a Justice of the Delaware Supreme Court, reported that he had "no reason to disagree" with Coates's conclusion. Id. at 847.

84. See, e.g., Jeffrey N. Gordon, Poison Pills and the European Case, 54 U. MIAMI L. REV. 839,840 (2000) ("I agree with Professor Coates that the empirical evidence on poison pills is difficult to assess ....").

85. See Coates, supra note 15 , at 313-14.

86. Kahan \& Rock, supra note 3 (manuscript at 27); see also id. ("[S]urprise pills-pills that were not predicted on the basis of general company characteristics-and 'morning-after' pills-which are adopted close to the time of a bid-have a particularly pronounced positive impact on acquisition premia."). Kahan and Rock also cite Professors Comment and Schwert to support this point. Id. (manuscript at 27-28) ("Even though [surprise pills and morning-after pills] also reduce the likelihood of a bid succeeding, their net impact on target shareholders is positive." (citing Comment \& Schwert, supra note 79, at 31,36)). The surprise pills discussed in the Comment and Schwert model, however, are still pre-bid pills, see Comment \& Schwert, supra note 79 , at $31 \mathrm{tbl.4,} \mathrm{which} \mathrm{provide} \mathrm{no} \mathrm{signal} \mathrm{on} \mathrm{willingness} \mathrm{to} \mathrm{resist} \mathrm{for} \mathrm{the} \mathrm{reasons} \mathrm{presented}$ here. In contrast, morning-after pills are post-bid pills, -which may plausibly reflect the target's willingness to resist, but here the econometric evidence is weak: Comment and Schwert find a statistically insignificant effect of morning-after pills using the standard methodology of comparing premiums in deals with and without pills $(t$-statistic $=0.61)$. See $i d$. at 36 . Only when Comment and Schwert examine "unconditional" premiums (defined as returns to all targets regardless of whether a bid is made) do they find a statistically significant effect of morning-after pills, see id., but this result is easily explainable by the fact that morning-after pills, by definition, are highly endogenous to bids, and bids produce large positive returns for target shareholders regardless of whether a pill is in place.

87. See, e.g., Coates, supra note 15 , at 301 (noting the "belief that companies that have adopted pills prior to a bid in fact resist more frequently than companies that have not," but also reporting "no empirical evidence supporting such a belief"). 
argument as well. ${ }^{88}$ As described by Robert Kindler, formerly a corporate partner at Cravath, Swaine \& Moore, and currently Global Head of Mergers \& Acquisitions at J.P. Morgan Securities,

Whether a company has a pill in place is not meaningful.... There are many companies that for lots of reasons don't have pills. I have always counseled-as a lawyer and as a banker-companies that don't have poison pills, that they should not put them in, because if you put a poison pill in all you're doing is attracting attention to yourself. I don't think it's a prudent thing to put a pill in place if you don't have one, because you can always put one in in a half an hour. ${ }^{89}$

\section{Anecdotal Evidence}

Disarmed of the pill premium evidence, some proponents of takeover defenses have resorted to the realm of anecdote to support their view. For example, Martin Lipton, along with his partner Mark Gordon, both describe Willamette's use of an ESB defense against Weyerhaeuser as (in Lipton's words) a "shining example of how a staggered board and poison pill operate to the benefit of shareholders." Weyerhaeuser launched a hostile bid for Willamette at $\$ 48$ per share in November 2000; Willamette resisted for fourteen months, lost a first proxy contest but retained board control due to its ESB, and finally sold to

88. See, e.g., Interview with Douglas Braunstein, Managing Director and Head of Investment Banking Coverage, J.P. Morgan Securities, in New York, N.Y. (June 3, 2003) [hereinafter Braunstein Interview] ("The lack of a pill is a function of the heritage of the company.... I don't think that the lack of one speaks to the willingness of a target to be a willing seller. I would also add that the presence of one doesn't necessarily speak to the willingness or unwillingness of someone to be a seller."); Interview with Stephen Munger, Co-Head of Global Mergers \& Acquisitions, Morgan Stanley, in New York, N.Y. (June 3, 2003) [hereinafter Munger Interview] ("Anyone can drop in a pill overnight. ... The only way I would put some significance on [the absence of a pill] is if a company said, 'We don't intend to use a pill under most circumstances.' I would pay attention to that, but I'm not aware of any company that has ever said that."). One interviewee expressed the opposite view: "[Pills] have become part of the woodwork, and so when you see those things don't exist, it means there is a problem, there is a weakness you can exploit." (This interviewee's identity remains anonymous for reasons cited infra note 101.) However, in a proprietary database of all hostile takeover bids between 1996 and 2002, constructed by Lucian Bebchuk, John Coates, and me, we find that no target was unable to put in a poison pill after the bid was launched, though some targets chose not to do so for other reasons (e.g., an imminent annual meeting for the unitary-board target would have made the pill meaningless). See Lucian Arye Bebchuk, John Coates IV \& Guhan Subramanian, Hostile Bids Database (on file with author) [hereinafter Bebchuk, Coates \& Subramanian, Hostile Bids Database].

89. Interview with Robert Kindler, Global Head of Mergers \& Acquisitions, J.P. Morgan Securities, in New York, N.Y. (June 4, 2003).

90. Martin Lipton, Pills, Polls, and Professors Redix, 69 U. CHI. L. REV. 1037, 1057 (2002); see also Gordon, supra note 3, at 834-35. 
Weyerhaeuser for $\$ 55.50$ per share, a $15.6 \%$ increase over Weyerhaeuser's initial offer. Professor Bebchuk responds that a $15.6 \%$ increase over a fourteen-month period was not a particularly good return for Willamette's shareholders, and offers Bosch Telecom's bid for Detection Systems as an example of a target achieving an even better improvement relative to the initial offer without the need for potent takeover defenses. ${ }^{91}$ Gordon counters that $15.6 \%$ was "actually quite strong" compared to the S\&P 500 and the relevant industry index during this fourteen-month period. ${ }^{92}$

The obvious problem with anecdotal evidence is that examples can be chosen selectively, without providing any sense for whether the particular case is representative or an outlier. In fact, a more systematic analysis demonstrates that Willamette's $15.6 \%$ increase is about average among all targets in the modern takeover era, including targets without strong defenses. There have been 30 successful hostile bids between 1996 and 2002: 9 against targets with ESBs (including Willamette), and 21 against targets without ESBs. ${ }^{93}$ Among these 30 bids, every bidder except one eventually paid more than its first publicly announced offer. ${ }^{94}$ The average increase over the initial offer was $14.8 \%$, broken down as $13.6 \%$ for ESB targets and $15.4 \%$ for non-ESB targets. Thus Willamette's bargaining power yielded a $0.8 \%$ greater increase than the average target was able to achieve and a $0.2 \%$ higher increase than the average non-ESB target was able to achieve. ${ }^{95}$ This difference, of course, is not statistically significant. In fact, though statistically insignificant, it is instructive to note that non-ESB targets achieved on average a $1.8 \%$ greater increase from the initial bid than ESB targets, a result that is directionally opposite from what Gordon, Lipton, and other proponents of the bargaining power hypothesis predict.

\section{A MODEL OF BARGAINING WITH DEFENSES}

In the previous Part, I challenged the arguments that have been put forward in support of the view that takeover defenses increase shareholder value when a company becomes a takeover target. I argued that structural coercion is largely a historical artifact; that substantive coercion is in

91. See Bebchuk, supra note 7, at 1031.

92. Gordon, supra note 3, at 835 .

93. See Bebchuk, Coates \& Subramanian, The Power of Takeover Defenses, supra note 6 , at 29 tbl.1.

94. See Bebchuk, Coates \& Subramanian, Hostile Bids Database, supra note 88.

95. Moreover, assuming a (conservative) $6 \%$ cost of capital, the fact that Willamette took fourteen months to achieve this increase, compared to approximately five months for the average target that sold to a hostile bidder, suggests that Willamette used its bargaining power to the detriment of its shareholders: The extra nine months would require an additional $4.5 \%$ increase in the premium received in order for the Willamette shareholders to earn a $6 \%$ annualized return; instead, the Willamette shareholders received an extra $0.8 \%$ return over this nine-month period. 
tension with the empirical evidence that shareholders of hostile bid targets, on average, do better when they sell; and that the bargaining power hypothesis cannot be supported by the pill premium studies or by the anecdotal evidence that has been put forward to date. Among these three arguments, the bargaining power hypothesis nevertheless remains plausible because (unlike the structural coercion and substantive coercion arguments) there is no theoretical model or empirical evidence to date that would clearly refute it. ${ }^{96}$ In this Part, I put forward a theory of bargaining in the "shadow" of takeover defenses using basic negotiation-analytic tools. I first develop a baseline model involving a bilateral monopoly between acquirer and target, no incremental costs of making a hostile bid, symmetric information, and loyal agents. In this stylized model I find clear theoretical support for the bargaining power hypothesis. I then relax each of these constraints, individually and additively, and find that the bargaining power hypothesis becomes considerably narrower in its scope of application.

Throughout this Part, I use evidence compiled from interviews with the heads or co-heads of mergers and acquisitions at ten major New York City investment banks. ${ }^{97}$ Using a database of all completed friendly acquisitions of U.S. public company targets announced between January 1990 and December $2002(n=6414),{ }^{98}$ I calculate the fraction of targets and acquirers that retained one of the firms represented by my interviewees. Table 1 reports the results.

96. Two recent theoretical analyses of the bargaining power hypothesis reach opposite conclusions. On the one hand, Professors Kahan and Rock argue that board entrenchment through takeover defenses is necessary in order for the board to have bargaining power against a potential bidder. See Kahan \& Rock, supra note 3 (manuscript at 14) ("If a board's power is not entrenched, any board decision can be overridden at any time by shareholders. But this makes it more difficult for the board to make credible threats or commitment or [to] employ other strategic devices."). On the other hand, Professor Bebchuk argues that management may have bargaining power even if shareholders have the right to circumvent the bargaining process and directly accept a bidder's offer. See Bebchuk, supra note 7, at 1008 ("[Shareholders] might defer to the board and take no action to remove management's bargaining mandate ... . But they ... might sometimes choose to take away the bargaining mandate and to accept the bidder's offer if they conclude that management's recommendation is likely the product of self-serving reasons or cognitive bias."). The problem with Kahan and Rock's analysis is that it moves no further than the baseline model presented here, failing to recognize alternatives away from the table, hostile bid costs, asymmetric information, and agency costs. As discussed in Section III.F, the introduction of these factors substantially calls into question the authors' conclusion that "the net effect of [a target board's bargaining power that arises from defenses] is likely to outweigh the loss from hostile bids blocked by staggered boards." Kahan \& Rock, supra note 3 (manuscript at 27). The problem with Bebchuk's argument is that, as demonstrated in the baseline model presented in Section III.A and described qualitatively by Kahan and Rock, a bidder's direct access to target shareholders would in fact reduce a target board's bargaining power.

97. For a list of the interviewees, see supra note 9.

98. This sample is larger than the sample I use in Part IV because of the exclusions noted in Subsection IV.A.1, notably the exclusion in Part IV of deals valued at less than $\$ 50$ million. 


\section{TABLE 1, REPRESENTATION OF INTERVIEWED FIRMS AMONG U.S. NEGOTIATED ACQUISITIONS, 1990-2002}

\begin{tabular}{|c|c|c|}
\hline & Deats $(\%)$ & Dent Yalue (\%) \\
\hline Advisor to target & 44.1 & 87.0 \\
\hline Advisor to acquirer & 53.6 & 88.5 \\
\hline $\begin{array}{l}\text { Advisor fo either } \\
\text { or boffi }\end{array}$ & 71.7 & 96.4 \\
\hline
\end{tabular}

Table 1 shows that the mergers and acquisitions departments headed by my interviewees accounted for ninety-six percent of deal value since 1990 , on either the buy side, the sell side, or both. ${ }^{99}$ While anecdotal evidence from practitioner interviews is of course subject to the same criticism that I describe with respect to the Willamette/Weyerhaeuser case study, ${ }^{100}$ I attempt to mitigate this concern by reporting here only representative quotations and noting differences of opinion where they exist. ${ }^{101}$

\section{A. Baseline Case: Bilateral Monopoly, No Hostile Bid Costs, Symmetric Information, and Loyal Agents}

I begin with a stylized takeover negotiation between the target board and the acquirer. ${ }^{102}$ Assume that the target's shares are widely held, and that the target board is loyal to its shareholders. Assume further that the acquirer and target have a bilateral monopoly--i.e., the only options for the target are a deal with the given acquirer or no deal at all, and the only options for the acquirer are a deal with the given target or no deal at all. Finally, assume that the target is worth $\$ 100$ as a stand-alone entity and

99. The lawyer market for negotiated acquisitions is much less concentrated. See John C. Coates IV, Explaining Variation in Takeover Defenses: Blame the Lawyers, 89 CAL. L. REV. 1301, 1325-26 (2001).

100. See supra text accompanying notes $93-95$.

101. See, e.g., supra note 88 ; infra notes $128,135,184$. Two of these quotes are anonymized because they are outlier views and are inconsistent with econometric evidence that was not made available to the interviewees at the time of the interviews. See supra note 88; infra note 184.

102. I thank Professor George Baker for helpful conversations in developing this baseline model. 
$\$ 200$ to the acquirer, and that the acquirer would incur no incremental costs (beyond the costs of the negotiated acquisition) in making a hostile bid.

With these assumptions in place, I introduce takeover defenses. For purposes of this baseline example I take only the two extremes: complete defenses, in which case the acquirer cannot gain control of the target unless the target board agrees to the acquisition; and no defenses, in which case the acquirer can make a take-it-or-leave-it, costless tender offer to the target's shareholders at any point in the negotiation with the target board. ${ }^{103}$ If such a take-it-or-leave-it offer is made, the target shareholders will tender if and only if the offer price is strictly greater than the stand-alone value of the target.

Finally, I assume common knowledge - that is, that the target board, the target shareholders, and the acquirer know all of these facts, and that all parties know that all parties know.

I begin with the case of no takeover defenses. The expected outcome in this case is that the acquiring company will make an offer of $\$ 101$ to acquire the target, which the target's board will accept. The reason is that the acquirer's walk-away alternative is to make a tender offer directly to the target shareholders for $\$ 101 .{ }^{104}$ Because there are no incremental costs to making a hostile bid, the acquirer will resort to a hostile bid as soon as the target board rejects $\$ 101$. Because $\$ 101$ is greater than $\$ 100$, the target shareholders will accept. Finally, because of the common knowledge assumption, the target board can predict this sequence of events ex ante and will therefore accept $\$ 101$.

Now consider the case of complete takeover defenses. In this scenario, the acquirer's walk-away alternative is no deal, with an expected profit of $\$ 0$. The acquirer knows that the target board will accept as little as $\$ 101$; the target board knows that the acquirer is willing to pay as much as $\$ 199$. The bargaining range in this negotiation, then, is [\$101, \$199]. Modeling this negotiation as a Nash bargaining game with equal bargaining weights yields an expected outcome of $\$ 150 .^{105}$

103. Therefore, a target with no defenses cannot put in a poison pill during the negotiations, either due to its jurisdiction, its charter, or perhaps a public announcement by its board that it would not do so without a shareholder vote.

104. Because the target shareholders cannot bargain with the acquirer, the acquirer can make a credible commitment to $\$ 101$ even though target shareholders are aware (under the common knowledge assumption) that the acquirer can pay up to \$199. See generally THOMAS C. SCHELLING, THE STRATEGY OF CONFLICT (1960) (discussing the power of commitment in negotiations). This collective action problem also mitigates the effect of faimess considerations in this arena. See MAX H. BAzERMAN \& MARGareT A. NEALE, Negotiating Rationally 117-21 (1992) (surveying experimental evidence on the influence of fairness considerations in negotiations).

105. In a Nash bargaining game, two players each request a certain amount of the surplus (here, $\$ 100$ ). If their requests are compatible (here, summing to $\leq \$ 100$ ), each player receives the amount requested; if their requests are not compatible (summing to $>\$ 100$ ), each player receives nothing. Assuming Pareto optimality, independent of irrelevant alternatives, symmetry, and 
This baseline example formalizes the mechanisms that underlie the bargaining power hypothesis. Surprisingly, despite the widespread acceptance of the bargaining power hypothesis (or perhaps because of it), no one has previously specified the underlying negotiation mechanisms that make it true. Here, we see bargaining power in action: Without takeover defenses, the target shareholders receive $\$ 101$; with takeover defenses, the target shareholders receive $\$ 150$ in expectation. In the remainder of this Part, I introduce a series of real-world factors that make the influence of takeover defenses on the negotiated outcome more ambiguous.

\section{B. Alternatives away from the Table}

As a starting point, I relax the assumption that the bidder and target negotiate in a bilateral monopoly situation. In the real world, both the target and the acquirer have options away from the table; among these alternatives, each party has a best alternative. While this point is obvious and comes out of basic negotiation theory, ${ }^{106}$ it has implications that have been overlooked by commentators to date: The existence of a walk-away alternative places a constraint, often an important constraint, on the ability of the target to extract more from the acquirer through the use of defenses. I now describe these constraints in more detail on both the buy side and the sell side, and examine the extent to which these constraints were relevant in the 1990s M\&A marketplace.

\section{Buy-Side Alternatives}

Beginning on the acquirer's side, consider a simple quantitative example. Using the assumptions from the baseline case, consider an acquirer that is negotiating with a target board that has complete defenses. In a bilateral monopoly situation, recall that the predicted outcome is $\$ 150$. But now assume that the acquirer has an alternative away from the table: an acquisition of a different target, $T_{2}$, which has identical assets. ${ }^{107}$ The price

invariance to positive linear transformations, the Nash bargaining game solution is that each player demands half of the surplus. See John Nash, Two-Person Cooperative Games, 21 ECONOMETRICA 128 (1953). Changing the bargaining weights of the players changes the division of the surplus but does not change any of the conclusions that follow regarding the bargaining power hypothesis. $C f$. RICHARD SHELL, BARGAINING FOR ADVANTAGE 189 (1999) (observing that the outcome in single-issue distributive negotiation is typically close to the midpoint of the two opening offers).

106. See ROGER FISHER ET AL., GETTING TO YES 99-100 (2d ed. 1991) (coining the acronym "BATNA" for "best alternative to a negotiated agreement").

107. See Interview with Louis P. Friedman, Global Head of Mergers \& Acquisitions, Bear, Stearns \& Co., in New York, N.Y. (June 2, 2003) [hereinafter Friedman Interview] ("A banker may approach the potential target and say, 'I was just with the CEO of [potential acquirer], his business plan is going this way or that way, you certainly are one of the companies that it would 
of this acquisition would be $\$ 101$, either because $T_{2}$ has no defenses, or because $T_{2}$ 's managers prefer a takeover to remaining independent. With the introduction of $T_{2}$, as soon as the price in the negotiation with $T_{1}$ goes above $\$ 101$, the acquirer will simply buy $T_{2}$ instead. ${ }^{108}$ Knowing this fact, a loyal $T_{1}$ board will agree to $\$ 101$ from the acquirer even if it has complete defenses, which is the same as the predicted outcome against the target. This simple example illustrates that the existence of walk-away alternatives caps (and, in the extreme case, eliminates) the effectiveness of takeover defenses as a bargaining tool.

Notice that this argument requires an opportunity cost in buying either $T_{1}$ or $T_{2}$ : If there were no such cost, then a value-maximizing acquirer should pay $\$ 150$ to acquire $T_{1}$ and $\$ 101$ to acquire $T_{2}$, for a total profit of $\$ 149(\$ 50+\$ 99)$. But in the real world, three factors point strongly toward an opportunity cost in buying either $T_{1}$ or $T_{2}$.

First, an acquirer often needs either $T_{1}$ or $T_{2}$ to fill a particular portfolio need. ${ }^{109}$ Take the recent example of Procter \& Gamble's acquisition of Wella AG, a German hair care company. As reported by the Wall Street Journal, P\&G bought Wella to "give P\&G a leg-up in its growing rivalry with L'Oréal." 110 But the Journal also reported that "[t]he talks mark P\&G's second attempt at buying a big German beauty firm," and that Wella was only considered after talks with Beiersdorf had broken down. ${ }^{111}$

make sense for him to combine with, but so are companies B or C.'"'); Interview with Howard Schiller, Co-Head of Global Industrial and Natural Resources Group (formerly Co-Head of U.S. Mergers \& Acquisitions), Goldman Sachs \& Co., in New York, N.Y. (June 4, 2003) [hereinafter Schiller Interview] ("A lot of times a client has expressed an interest in developing a business, getting into a new business, and has asked us to help them in thinking through who the targets may be, the feasibility of these targets, financibility, and also receptivity. So it's a funnel. We start with a lot of companies and start narrowing it down.").

108. See Friedman Interview, supra note 107 ("If there are more alternative targets for a potential acquirer, it is certainly going to be the case that you're not going to stretch as far on price, or governance terms, or whatever the issues are. You will have greater conviction to staying closer to what you view as value-enhancing for your own shareholders.... And that general thought is going to be the same in the target's analysis of how it treats any particular issue relative to the set of potential alternatives that are available to it."); $c f$. Interview with Donald Meltzer, Vice Chairman of Investment Banking and Co-Head of Global Mergers \& Acquisitions, Credit Suisse First Boston, in New York, N.Y. (June 2, 2003) [hereinafter Meltzer Interview] ("Weaker defenses may not enable you to pay a lower price, but it probably makes it more likely that you're going to pursue that company rather than another company that has better protections.").

109. See, e.g., Meltzer Interview, supra note 108 ("There certainly have been situations where we've known that a buyer was about to do a deal, that this was our best buyer, and we got wind that they might be talking to the other target, so we would hustle up to get the buyer focused on us.").

110. Sarah Ellison \& Robin Sidel, P\&G Holds Talks on Buying Wella, WALL ST. J., Mar. 3, 2003 , at A3.

111. See id. ("The Cincinnati consumer-products giant had been trying to woo Beiersdorf AG, maker of Nivea lotions, but those negotiations have stalled because of a standoff between the company's two major shareholders, Allianz AG and the Tchibo family, and disagreements about price."). 
This account suggests that $P \& G$ needed to acquire one, and only one, German beauty products company in order to fill a strategic need. ${ }^{112}$

Second, acquisitions generally require substantial managerial time and effort in order to ensure smooth integration. According to Donald Meltzer, Vice Chairman of Investment Banking and Co-Head of Global Mergers \& Acquisitions at Credit Suisse First Boston,

I think that particularly these days companies are very cognizant of the management time it takes to execute transactions. I don't mean negotiating an agreement, I mean buying the company, integrating the company, and managing it as a combined enterprise.... I think there is a much greater awareness-call it lack of hubris-about how much management time it will take to implement a new acquisition, and hence there is also a sense of how much management depth is required to do that. And so I think for all of those reasons people are concerned about doing multiple deals at the same time.

The fact that the Delaware Supreme Court has upheld a breakup fee of $\$ 550$ million in part on the basis of opportunity cost also supports the view that managerial attention can only be focused on one acquisition at a time. ${ }^{114}$

Third, a company that makes an acquisition for cash may have difficulty making further cash acquisitions due to balance sheet constraints. Oracle's recent (and currently ongoing) effort to buy PeopleSoft illustrates this point: Immediately after Oracle announced its hostile cash bid, Moody's downgraded its outlook for Oracle to "negative," citing the additional cash that Oracle would need to complete its deal. ${ }^{115}$ If its PeopleSoft bid is successful, Oracle will have difficulty making further cash acquisitions until it reduces its leverage.

112. Cf. Peter Fritsch, Hercules Is Still Hoping for Grace Deal, but Is Studying Other Merger Prospects, Wall ST. J., Mar. 13, 1996, at B6 ("[Hercules President R. Keith] Elliott quickly added, 'Grace is just one option, and I can't tell you more than that.' He said Hercules continues to maintain a 'short list' of possible candidates for a 'major transaction,' though he didn't elaborate."). After Grace spurned Hercules's offer, Hercules made unsuccessful bids for four units of Unilever in January 1997 and for Allied Colloids in January 1998. See Susan Warren, Hercules, Jilted Three Times, Pines for an Acquisition, WALl ST..J., Feb. 12, 1998, at B4 ("Hercules Inc. has spent much of the decade trimming down and gussying up. Still, the big specialty-chemicals concem can't get a good date."). In July 1998, Hercules finally bought BetzDearborn for \$2.4 billion. See Steven Lipin \& Susan Warren, Hercules Agrees To Acquire BetzDearborn, WALL ST. J., July 30, 1998, at A3.

113. Meltzer Interview, supra note 108.

114. See Brazen v. Bell Atl. Corp., 695 A.2d 43, 49 (Del. 1997) ("Is the liquidated damages provision here within the range of reasonableness? We believe that it is, given the undisputed record showing the size of the transaction, the analysis of the parties concerning lost opportunity costs, other expenses and the arms-length negotiations." (emphasis added)).

115. See David Bank, Moody's Downgrades Oracle's Outlook, Citing PeopleSoft Bid, WALL ST. J., June 12, 2003, at B4. 
In short, strategic need, management attention, and financing constraints all suggest that acquisitions impose an opportunity cost that often crowds out further acquisitions. Because of this fact, buy-side alternatives may constrain the bargaining range in negotiations with any particular target.

\section{Sell-Side Alternatives}

Sell-side alternatives away from the table may constrain the bargaining range as well. ${ }^{116} \mathrm{~A}$ recent empirical study examining sale processes initiated by fifty publicly traded companies during the 1990 s finds that, on average, sell-side bankers contacted 63.2 buyers for each selling company; from those contacted, 28.7 buyers indicated interest by signing confidentiality agreements; among these firms, 6.3 continued further due diligence or submitted preliminary proposals; and among these, 2.6 submitted binding written offers. ${ }^{17}$ And to the extent that this kind of process is not successful in generating adequate competition among buyers, the corporate laws of all states require target shareholder approval for fundamental transactions such as mergers. ${ }^{118}$ If a higher-value bidder exists, that bidder can use the window between the initial deal announcement and the target shareholder vote to make a higher bid for the target. ${ }^{119}$ Although deal protection terms such as stock option lockups and breakup fees might protect the initial deal to some extent from being "jumped" by a third party, as a legal matter these deal protection devices cannot completely eliminate the possibility of an overbid. ${ }^{120}$ Finally, certain transactions are subject to

116. See, e.g., Martin Peers, Blockbuster, Columbia House in Merger Talks, WaLL ST. J., Sept. 19, 2003, at B1 ("Aside from Columbia House, [Blockbuster CEO] Antioco is looking at other possible deals. Investment bankers have said Blockbuster could merge with an online retailer or a videogame chain.").

117. See Audra L. Boone \& J. Harold Mulherin, Corporate Restructuring and Corporate Auctions 41 tbl.10 (Nov. 2002) (unpublished manuscript, on file with author).

118. See, e.g., DEL. CODE ANN. tit. 8, $\S 251$ (c) (2001); see also REVISED MODEL BUS. CORP. ACT $\S 11.04(b)(1983)$.

119. See, e.g., Guhan Subramanian, The Drivers of Market Efficiency in Revlon Transactions, 28 J. CORP. L. (forthcoming Nov. 2003) (manuscript at $15 \mathrm{n} .74$, on file with author) (quoting Interview with Blaine V. Fogg, Partner, Skadden, Arps, Slate, Meagher \& Flom, in New York, N.Y. (June 15, 2000) ("I had a situation recently [in which the] buyer was foreign, and needed the U.S. management. Now there was another company out there who was probably likely to pay a higher price, but the target didn't want to talk to them. So what do you do? They announced their deal; the other bidder came in and bid a high price and they won.")).

120. See John C. Coates IV \& Guhan Subramanian, A Buy-Side Model of M\&A Lockups: Theory and Evidence, 53 STAN. L. REV. 307, 390 n.240 (2000) (quoting Interview with Robert E. Spatt, Partner, Simpson Thacher \& Bartlett ("It tends to be the lawyers [negotiating lockups], being able to tell the bankers, 'Hey, when you get into the board room, you're going to have to make sure you tell the board that you don't think that whatever it is that's been agreed to would be an undue impediment.' And that's something I try to get investment bankers to tell boards, because that is the underpinning under the case law of what it should be.")). An exception used to 
so-called Revlon duties, in which the initial bidder and target must leave the deal relatively unprotected in the event that a higher-value bidder should appear. $^{121}$

To summarize, once a target has decided to sell itself, the typical process involved in "shopping the company," the shareholder vote requirement, and the additional constraints imposed by Revlon make sellside alternatives important in many if not most negotiated acquisitions. ${ }^{122}$ These features of a sale process have implications for the bargaining power hypothesis. Consider a situation in which the target has no defenses, and in the baseline case would agree to be acquired for $\$ 101$. But if another bidder would be willing to pay up to $\$ 130$, for example, then the bidder at the table might be forced to offer more in the initial negotiation with the target regardless of the target's defenses. ${ }^{123}$

\section{Application to the 1990 s M\&A Marketplace}

The extent to which alternatives away from the table impose constraints on the bargaining range depends on the "thickness" of the market for corporate control. If the market is thin, then the bilateral monopoly assumption is plausible and defenses might provide bargaining power in the takeover negotiation. But if the market is thick, then the bilateral monopoly assumption becomes more problematic because other potential buyers and sellers constrain the bargaining range. In this environment, defenses are less effective in influencing the outcome.

Which description better characterizes the 1990s M\&A marketplace? Clearly, the 1990s market was the thickest in U.S. corporate history, with an unprecedented level of deal activity in terms of both the number of deals and total deal value. ${ }^{124}$ Moreover, the fact that deal activity clustered by industry during the $1990 \mathrm{~s}^{\text {save }} \mathrm{e}^{125}$ suggests an amplification of bargaining range constraints: When one acquirer-target pair was engaged in takeover negotiations, other players in the same industry were also more alert to

be so-called "pooling-killing" lockups, which are no longer relevant after the elimination of pooling accounting in June 2001. See infra note 197.

121. See Revlon, Inc. v. MacAndrews \& Forbes Holdings, Inc., 506 A.2d 173, 183-84 (Del. 1986); see also Mills Acquisition Co. v. Macmillan, Inc., 559 A.2d 1261, 1282 (Del. 1989) (enjoining a lockup agreement for a deal in Revlon mode).

122. See, e.g., JAMES C. FREUND, Lying in Negotiations, in THE ACQUISITION MATING DANCE AND OTHER ESSAYS ON NEGOTIATING 157, 157 (1987) (noting a negotiation situation in which the acquirer asked the target's representatives whether there were other potential buyers).

123. See Braunstein Interview, supra note 88 ("If there is a third party that is interested in acquiring that target, the value opportunity potential created by that third party clearly must be factored into the original acquirer's pricing.").

124. See Joseph H. Flom, Mergers \& Acquisitions: The Decade in Review, 54 U. MIAMI L. REV. 753, 753-54 (2000).

125. See Mark L. Mitchell \& J. Harold Mulherin, The Impact of Industry Shocks on Takeover and Restructuring Activity, 41 J. FIN. ECON. 193, 221 (1996). 
takeover possibilities. Practitioner interviews indicate that buyers and sellers in most situations were considering several alternatives in the 1990s marketplace. Stephen Munger, Co-Head of Global Mergers \& Acquisitions at Morgan Stanley, describes the way he approaches a buy-side process:

The way we conduct our business is pretty continuous daily contact with our strategic clients about a range of alternatives, and how the comparative risks and benefits of those different alternatives change over time. ... Alternatives assessment is important for two reasons. First, it means you're not missing anything. And second, these are complicated judgments you're making, and I've often found that figuring out the right thing to do is easy if you're comparing two things. It's like deciding what art you like-you put two pictures side by side and you decide which one you like better. Or an eye test-which is sharper? You don't have to sit there and analyze the sharpness of the individual thing, you just compare. So comparing alternatives is a very efficient way to get everyone's head around what is the best thing for us to do. ${ }^{126}$

And Howard Schiller, Co-Head of Global Industrial and Natural Resources Group at Goldman Sachs, ${ }^{127}$ describes the competition that typically ensues on the sell side:

It's very common to talk to multiple buyers to "shop the company" in order to get the highest price. You want to balance the number of buyers against the desire to keep things quiet. ... The more people you talk to, the greater the chance of leaks. ... But there is nothing like a competitor to push the price up. ${ }^{128}$

If alternatives away from the table are significant, then defenses become less important, and potentially unimportant, in determining the bargaining range. ${ }^{129}$ According to Douglas Braunstein, Managing Director and Head of Investment Banking Coverage at J.P. Morgan Securities, "The overwhelming factor that influences price is third-party alternatives, to the

126. Munger Interview, supra note 88.

127. Before an internal restructuring in June 2002, Mr. Schiller was Co-Head of U.S. Mergers \& Acquisitions at Goldman Sachs.

128. Schiller Interview, supra note 107; $c f$. Meltzer Interview, supra note 108 ("Walk-away alternatives are more prevalent on the sell side than on the buy side, because it's somehow more believable that I've talked to another person and they are ready to buy my company. It's less typical that there is the exact comparable thing to buy. But that is definitely a factor in some decisionmaking, particularly if there is a scarcity of acquirers.").

129. See, e.g., Meltzer Interview, supra note 108 ("In order for defenses to be materially relevant in some meaningful number of cases, you have to have a board which is really prepared to use them as a lever in the negotiation, and I think that boards have a lot of other mechanisms for creating a competitive process or a lever to enhance the value that shareholders are receiving."). 
extent that third-party alternatives exist. . . . If you've got three well-heeled bidders competing for a company, the fact that the target had a staggered board or a poison pill became unimportant well before that bidding process ensued."130 This thickness in the 1990s marketplace suggests that alternatives away from the table may make the influence of takeover defenses smaller than defense proponents have suggested. ${ }^{131}$

\section{Hostile Bid Costs}

The prior Section makes the following basic point: In any negotiation, bargaining power affects the distribution of the surplus within the constraints imposed by walk-away alternatives. As these constraints become more severe, the potential for bargaining power to influence the negotiated outcome becomes smaller. Of course, the fact that alternatives away from the table might narrow the bargaining range does not mean that the bargaining power hypothesis might not be working within this narrower range. The introduction of hostile bid costs, however, further reduces the influence of defenses. If these costs are sufficiently large, then a hostile bid may be precluded as a structural matter, which would make the actual target defenses irrelevant (not just less important) in determining the final deal price. In this Section, I explain these points in more detail.

\section{Fixed Costs, Independent of Defenses}

Consider again a baseline scenario in which the target has no takeover defenses, and assume that alternatives away from the table have narrowed the bargaining range to [\$130, $\$ 150]$. So, for example, the target board must get at least $\$ 130$ in order to avoid being jumped by an outside bidder, and at $\$ 150$ the acquirer has a better alternative in buying some other

130. Braunstein Interview, supra note 88; see also Friedman Interview, supra note 107 ("I think that a more meaningful influence on price [than defenses] is just the presence of actual or potential competitive bidders."); Meltzer Interview, supra note 108 ("In how many situations do defenses provide my principal negotiating leverage? In most situations, if it's a strategic acquirer, there is a decent chance that there is another strategic acquirer, and your price tension is created by your competitive process, not by hiding behind your shark repellents.").

131. It might nevertheless be argued that defenses allow the target to improve its alternatives away from the table. This argument only applies once a hostile bid has been announced, because until that point the buyer has not brought pressure to bear on the target in a way that would make time critical. (Or put differently, until the buyer goes hostile, the target does not face time pressure in finding a higher-value bidder.) Bebchuk, Coates, and I have found, however, that hostile bid targets with strong defenses are slightly less likely (not more likely) to sell to a white knight than targets with weaker defenses. See Bebchuk, Coates \& Subramanian, Powerful Antitakeover Force, supra note 6, at 930. Instead of using potent defenses to find a higher-value buyer, it seems that the typical ESB target uses defenses to resist the hostile bidder and to remain independent. See id. at 934. 
company. Against no defenses, the expected outcome is $\$ 131$; against complete defenses, the expected outcome is $\$ 140$. $^{132}$

Now assume that the acquirer would need to spend $\$ 10$ in order to launch a hostile bid, regardless of what the target's defenses are, and that this new assumption is also common knowledge. The $\$ 10$ cost of making a hostile bid changes the expected outcome against a target with no defenses, because the bidder should be willing to pay as much as $\$ 140$ in order to avoid hostile bid costs of $\$ 10$. Again, modeling the negotiation as a Nash bargaining game yields an expected outcome at the midpoint of the bargaining range, at $\$ 135$, even in the absence of takeover defenses. In effect, the target gains bargaining power from the introduction of hostile bid costs because the bidder is no longer indifferent between a negotiated acquisition and a hostile bid, holding deal price constant.

If hostile bid costs are increased to $\$ 20$, analogous logic indicates that the bidder should be willing to pay $\$ 150$ in order to avoid hostile bid costs, and the expected outcome is therefore $\$ 140$ against a target with no defenses. This outcome is the same as the predicted outcome against complete defenses. In fact, with hostile bid costs greater than $\$ 20$ (the size of the bargaining range), there is no price at which the acquirer would prefer to make a hostile bid. If the target does not agree to a deal, the acquirer prefers simply to go to its walk-away alternative.

These two numerical examples indicate that the introduction of hostile bid costs pushes the predicted outcome against a target with no defenses toward the predicted outcome against a target with complete defenses. In the extreme, if hostile bid costs are greater than the width of the bargaining range, then a hostile bid is structurally precluded, and the expected outcome against no defenses is the same as the expected outcome against complete defenses. The intuition for this result is that if hostile bid costs are sufficiently large, then alternatives away from the table rather than takeover defenses are the binding constraint in the takeover negotiation. And if takeover defenses are not a binding constraint, then they cannot influence the final outcome.

Whether and to what extent hostile bid costs reduce the influence of takeover defenses in negotiated acquisitions thus turns on the magnitude of these costs. While I do not attempt to answer this question directly (and its answer is no doubt highly context-specific), in the remainder of this Subsection, I put forward three categories of hostile bid costs: bidder out-of-pocket costs, bidder reputational costs, and costs imposed on the target. Taken together, these three costs suggest that a hostile bid may be precluded in many, if not most, negotiated acquisitions. 


\section{a. Bidder Out-of-Pocket Costs}

The clearest costs of launching a hostile bid are the bidder's additional out-of-pocket expenses, such as additional financing costs (because hostile bidders typically offer cash), tender offer information agents, proxy solicitors, printing and advertising costs, and additional banker and lawyer fees. On the last element, although the market for law firms capable of advising in a hostile context is deeper than it was in the fights of the 1980s (which were dominated by Skadden, Arps on the acquirer side and Wachtell, Lipton on the target side), a hostile bid usually requires the involvement of one among an elite group of high-priced New York City law firms, typically in addition to local and in-house counsel. ${ }^{133}$ Furthermore, although not strictly an out-of-pocket cost, the diversion of managerial focus on the acquirer side may be an important element of the overall cost of making a hostile takeover bid. ${ }^{134}$

\section{b. Bidder Reputational Costs}

Second, making a hostile bid imposes reputational costs on the bidder, because future targets may be less willing to initiate negotiations with a bidder that has previously made a hostile takeover bid. ${ }^{135}$ Even if a future target were willing to negotiate with such a bidder, it may be more cautious, less forthcoming, and less willing to explore value-creating opportunities than it would be with a bidder that had never made a hostile bid or had explicitly relinquished the hostile bid weapon. ${ }^{136}$ Michael

133. Five firms, all headquartered in New York City, accounted for $85 \%$ of the market for acquirer-side outside counsel in hostile takeover situations between 1996 and 2002: Skadden, Arps, Slate, Meagher \& Flom (35\% share); Simpson Thacher \& Bartlett (15\%); Sullivan \& Cromwell (13\%); Cleary, Gottlieb, Steen \& Hamilton (12\%); and Fried, Frank, Harris, Shriver \& Jacobson (10\%). See Bebchuk, Coates \& Subramanian, Hostile Bids Database, supra note 88.

134. See supra text accompanying note 113.

135. See, e.g., Braunstein Interview, supra note 88 ("Some buyers will say regardless of the importance I am not interested in pursuing an unfriendly transaction even if I want to do so here, because it will preclude me if I've done so from having a whole series of other conversations with other partners who may be concerned about my willingness to go unfriendly."); Interview with Steve Wolitzer, Global Head of Mergers \& Acquisitions, Lehman Brothers, in New York, N.Y. (June 4, 2003) [hereinafter Wolitzer Interview] ("No one wants to enter into a negotiated acquisition with a guy holding a club."). But see Interview with Michael J. Biondi, Chairman of Investment Banking, Lazard Frères \& Co., in New York, N.Y. (June 4, 2003) [hereinafter Biondi Interview] ("It cuts both ways. With some companies that have done hostiles before, you could argue that they may have the baggage of folks not wanting to talk to them. In other cases, other competitors might say, 'Those guys at XYZ are aggressive, so if they want this I'm not going to compete because even if I won I wouldn't be happy with the price."').

136. See, e.g., Munger Interview, supra note 88 ("If you create a sense of risk on their part to even be talking to you, it's a tougher thing to deal with in getting something done.... It's been my observation that working with a target is usually a better way to get a deal done than assuming a more threatening posture."); $c f$. Interview with James Neissa, Managing Director and Co-Head of Mergers \& Acquisitions, UBS Investment Bank, in New York, N.Y. (June 4, 2003) 
Biondi, Chairman of Investment Banking at Lazard Frères, describes how giving up the hostile threat can facilitate productive discussions:

Practically speaking, the hostile bid is not a particularly useful card to try to play. It's more amateurish than anything else. It's bad mood music if you want people to romance each other, to have that kind of a threat hanging back there, and I think it would in most cases diminish the likelihood of serious discussions. ${ }^{137}$

Perhaps as a result, many companies in the 1990s publicly committed to not making hostile bids. ${ }^{138}$ Tyco International, for example, had such a policy, and followed it to such a degree that it withdrew a hostile bid that had already been made by a company (U.S. Surgical) that Tyco acquired. ${ }^{139}$ In a statement to analysts after the announcement of Tyco's acquisition of U.S. Surgical, now-infamous Tyco CEO L. Dennis Kozlowski stated with respect to the outstanding bid for Circon: "[W]e're not big on hostile bids. In fact, we don't do them." categorical concession if the reputational benefits of disavowing the hostile bid weapon ex ante exceed any benefits of retaining the hostile bid weapon in particular negotiations. ${ }^{141}$

\section{c. Costs Imposed on the Target}

Finally, making a hostile bid often imposes costs on the target that make it less attractive for the bidder to acquire, in two respects. First, a hostile bid causes operational disruption. Target management and board

[hereinafter Neissa Interview] ("If you knew that you had somebody locked up with a standstill for three years, they aren't going to do a darn thing, sure, you might be a lot more open sharing information, walking them through the business, than if they signed a one-month standstill.").

137. Biondi Interview, supra note 135. Others use the "romance" analogy as well. See, e.g., Wolitzer Interview, supra note 135 ("We actually recommend that managers 'date' before we get to price or anything else. We'll say, 'You need to get together a number of times, have dinner off-site, go have some chats, go talk about the companies, make sure that you all think this will work. Then come back to us and we'll talk to you about structure and price and the rest of it, but we really need to know that you are comfortable with where you are headed with all this."').

138. See, e.g., Braunstein Interview, supra note 88 ("There are clearly clients who say that they are not interested in hostiles.").

139. See Brian J. Hall, Christopher Rose \& Guhan Subramanian, Circon (A), at 14-15 (Harvard Bus. Sch., Case Study No. 9-801-403, 2001).

140. Id. at 14.

141. One question is why a bidder would categorically dismiss the hostile bid possibility when it could do so in individual transactions through contract. See infra Section III.D. One reason might be that a reputation for not making hostile bids increases the likelihood of being approached by a potential seller. That is, a seller might be more likely to initiate a transaction with a buyer who has publicly and categorically disavowed the hostile bid weapon. I thank Professor Louis Kaplow for this point. 
time is diverted from managing the business, ${ }^{142}$ any difficulties that motivated the hostile bid receive greater publicity and scrutiny, ${ }^{143}$ and key employees may leave for competitors, even though their jobs are not explicitly at risk. ${ }^{144}$ Even if the bidder is not successful and ex post this cost is borne by the target, ex ante it increases the acquirer's willingness to pay in a friendly transaction by the magnitude of the cost multiplied by the acquirer's estimated likelihood of success. ${ }^{145}$

A second cost is that making a hostile bid may make post-deal integration more difficult (assuming that the deal is successful) because of the animosity generated by the process itself. ${ }^{146}$ As Gregg Polle, Co-Head of Mergers \& Acquisitions at Citigroup Global Markets, puts it,

Hostile deals get fought out in the public realm. When you're announcing a deal, you don't want your investors and the public

142. Circon CEO Richard Auhll described the experience of "managing under siege" from U.S. Surgical:

The workload during this hostile takeover attempt was the highest of my professional career. Of course, we had all the normal tasks of running a corporation, but on top of this [we were] managing outside consultants; ... building morale among employees; ... giving white knight and white squire presentations; . . . and beginning a major cost-cutting program.

Hall, Rose \& Subramanian, supra note 139, at 13.

143. See, e.g., Robin Sidel, Alltel Presses Offer for CenturyTel, Disparaging Sale of Wireless Unit, WALL ST. J., Aug. 28, 2001, at B4.

144. See Meltzer Interview, supra note 108 ("Just because something is a public company doesn't mean you can buy it on an unfriendly basis. If management is going to walk out the door the moment you're closed, you've got a lot of vulnerability there. Certainly for companies where the assets walk out the door every night-companies where intellectual property is very important - it's generally viewed as being very difficult to buy those companies on an unfriendly basis."). But see Mylene Mangalindan et al., Software Assault: Oracle's Bid for PeopleSoft Offers Possible Taste of Future, WALL ST. J., June 9, 2003, at Al ("Hostile takeovers historically are rare in technology because tech companies' most valuable assets-their employees-historically have been able to jump to rivals if they are unhappy with any corporate turmoil. But the pinched tech job market may make engineers think twice about walking out the door.").

145. Operational disruption costs may also reduce the target's reserve price: If operational costs would reduce the post-bid share price of the target's stock, or if operational costs are incurred before a friendly bidder can appear, then operational costs also reduce the target's reserve price. But if the target's walk-away alternative is unaffected by operational costs, then these costs will not reduce the target's reserve price. For example, if a target has a firm alternative offer of $\$ 130$, then the target board will not accept $\$ 125$ in order to avoid operational disruption costs of $\$ 10$; rather, the acquirer must offer at least $\$ 131$ in order to prevent the target from selling to the alternative bidder. In this scenario, operational disruption costs would operate unambiguously to increase the acquirer's reserve price without changing the target's reserve price.

146. See, e.g., Braunstein Interview, supra note 88 (citing the ability "to do a better job integrating post-acquisition" as an important reason that "in almost every instance" acquirers prefer to do a deal on a friendly basis). This preference might also provide an altemative explanation for Professor Schwert's finding that premiums in hostile deals are higher than premiums in negotiated deals. See G. William Schwert, Hostility in Takeovers: In the Eyes of the Beholder?, 55 J. FIN. 2599, 2630 (2000). While Schwert interprets this result to mean that "hostility is the outcome of aggressive bargaining by target managers," id., an alternative explanation is that a bidder must have a higher willingness to pay in order to go forward with a hostile offer. 
seeing sausage being made. You want to be able to go out and say, "Here's the deal." Everybody smiles, shakes hands, says it's a great deal, here's what the synergies are, etc. Present it to all of your constituencies-your investors, your employees, your regulator, the communities you do business in-and deliver it wrapped up in a bow. When you do a hostile deal, you're making sausage in front of people, and it's ugly sausage, because the other guy is trying to fight you off by saying all the reasons why the deal is bad. ${ }^{147}$

To summarize, these three categories of costs-bidder out-of-pocket costs, bidder reputational costs, and costs imposed on the target-reduce the influence of takeover defenses on the negotiated outcome. ${ }^{148}$ And if these costs are greater than the bargaining range in a particular negotiation, then a hostile bid is structurally precluded, and the target's defenses are irrelevant for the outcome of the negotiation. Manifesting this point, practitioners state that most bidders do not consider the hostile bid to be a meaningful weapon in a negotiated acquisition. ${ }^{149}$

\section{Costs That Are Increasing with the Level of Defenses}

The previous analysis identified three costs of making a hostile bid that are independent of the target's particular defenses. I demonstrated that these costs reduce and may eliminate the influence of takeover defenses on negotiated acquisitions. But even if hostile bid costs do not eliminate the influence of takeover defenses, the bargaining power hypothesis in its current form still requires that hostile bid costs increase over the particular range of defenses that is currently at issue. No academic commentator today questions the Williams Act or the right of a target board to maintain a pill for a limited period of time, in order to identify a higher-value buyer or to inform shareholders about the bid. ${ }^{150}$ The policy debate today focuses

147. Interview with Gregg Polle, Co-Head of Mergers \& Acquisitions, Citigroup Global Markets, in New York, N.Y. (June 2, 2003) [hereinafter Polle Interview].

148. There is also a hostile bid cost in the form of a benefit foregone, in that an acquirer in a negotiated acquisition can receive deal protection. These stock option lockups and breakup fees significantly increase the likelihood that the bidder will be able to close its deal. See Coates \& Subramanian, supra note 120 , at 332-34, 347-52.

149. See, e.g., Munger Interview, supra note 88 ("The vast majority of the time, you get a client who says, 'Look, I'm not interested in going hostile with this thing. Let's just put that off the table. ... Fundamentally, I don't want all the management fallout issues, etc., of a hostile.' It's a relatively rare thing to say the hostile weapon is our primary option or even something we want to explore deeply."); Neissa Interview, supra note 136 ("Most people will only do friendly deals. ... And in a friendly, if it's truly friendly, I don't really care about the defenses, except perhaps for some value in keeping an interloper from trumping a deal post-announcement ....").

150. See, e.g., Bebchuk, Coates \& Subramanian, Reply to Participants, supra note 6, at 896-97. This consensus did not exist twenty years ago. Compare Frank H. Easterbrook \& Daniel R. Fischel, The Proper Role of a Target's Management in Responding to a Tender Offer, 94 HARV. L. REV. 1161 (1981) (arguing that target managers should be required to remain passive 
within a relatively narrow range, on the prolonged use of more potent pills such as "Just Say No" pills, ESB pills, and dead hand or slow hand pills. That is, today's debate focuses not on whether a target board can maintain defenses, but rather for how long. ${ }^{151}$

If the bargaining power hypothesis is meant to advance the position of defense proponents within this debate, the general claim that defenses yield higher premiums in negotiated acquisitions becomes a more specific claim that more potent. pills yield higher premiums beyond what the wellaccepted baseline defenses provide. Implicit in this more specific claim is the assumption that if some defenses provide some bargaining power, then strong defenses must provide greater bargaining power-that is, bargaining power is monotonically increasing in the target's defenses.

To illustrate this point quantitatively, consider again a bargaining range of $[\$ 130, \$ 150]$. Further assume that hostile bid costs independent of the target's defenses are $\$ 10$, so that a hostile bid is not structurally precluded. In this scenario, the acquirer should be willing to pay up to $\$ 140$; at $\$ 141$, it prefers to make a hostile bid of $\$ 130$ and incur hostile bid costs of $\$ 10$. A Nash bargaining game predicts a negotiated outcome of $\$ 135$.

Now consider the influence of a potent defense such as an ESB. If an ESB would impose an additional $\$ 10$ cost on the bidder, then using similar logic the acquirer should be willing to pay up to $\$ 150$ in a negotiated acquisition, yielding a predicted negotiated outcome of $\$ 140$. This analysis is consistent with the bargaining power hypothesis, in that stronger defenses lead to a higher predicted outcome ( $\$ 140$ versus $\$ 135$ ). But it appears only in the set of circumstances in which hostile bid costs (independent of the target's defenses) are smaller than the width of the bargaining range and increasing over the range of defenses that is at issue in the current debate. Figure 3 illustrates this point graphically.

against a hostile tender offer), with Lucian Arye Bebchuk, The Case for Facilitating Competing Tender Offers, 95 HARV. L. REV. 1028 (1982) (arguing that target managers should be allowed to use defensive tactics in order to facilitate an auction), and Ronald J. Gilson, Seeking Competitive Bids Versus Pure Passivity in Tender Offer Defense, 35 STAN. L. REV. 51 (1982) (same).

151. See Bebchuk, Coates \& Subramanian, Reply to Participants, supra note 6, at 895-98. 


\section{FiguRE 3. RELATIONSHIP BETWEEN Hostile Bid COSTS AND TARGET'S DEFENSES}

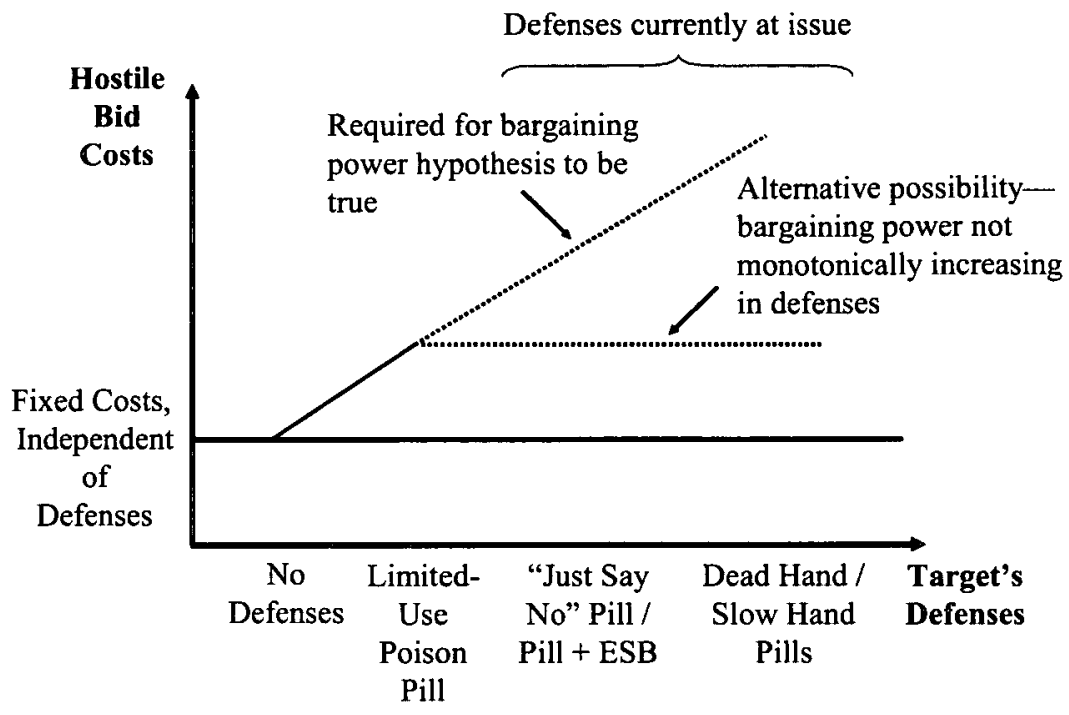

Figure 3 illustrates the point that potent defenses could yield greater bargaining power for the target board (i.e., the dotted diagonal line) or no further bargaining power beyond what a limited-use poison pill provides (i.e., the dotted flat line). Consider, for example, the possibility that defenses improve the target's bargaining power only by giving the target additional time to search for a higher-value buyer, i.e., a white knight. Then the question illustrated in Figure 3 is whether thirteen months (as provided by an ESB), ${ }^{152}$ or nineteen months (as provided by Maryland), ${ }^{153}$ or an indefinite period of time (as provided by Georgia, Pennsylvania, and Virginia) $^{154}$ is more valuable than the few months that a limited-use pill provides.

152. See Bebchuk, Coates \& Subramanian, Powerful Antitakeover Force, supra note 6, at 918 tbl.1.

153. Maryland permits companies to adopt a staggered board without the need for shareholder approval, see MD. CODE ANN., CORPS. \& ASS'NS § 3-803 (1999 \& Supp. 2002), which forces a bidder to win two annual elections of directors in order to take control of the board. Maryland permits thirteen months between annual meetings, see Coates, supra note 99, at 1403, and the additional endorsement of slow hand pills requires the bidder to wait another six months after gaining board control before it can redeem the target's pill, see MD. CODE ANN., CORPS. \& ASS'NS $\S 2-201$ (c)(2)(ii) (Supp. 2002). In total, a hostile bidder must wait a minimum of nineteen months before it can redeem a Maryland target's pill.

154. See supra notes 37-39 and accompanying text. 
Empirical evidence can shed some light on this question. Among hostile takeover attempts between 1996 and 2002, there have been twenty white knight searches conducted under pressure from an existing hostile offer. ${ }^{155}$ Among these twenty searches, eighteen targets found white knights within six months of the initial hostile bid announcement, that is, within the time frame that a target board might reasonably use a limited-use pill to explore strategic options or inform its shareholders, and within the time frame that target shareholders would likely defer to the target board's judgment if faced with a proxy contest.

The two exceptions are Hilton's hostile bid for ITT in January 1997 (in which ITT sold itself to Starwood ten months later), ${ }^{156}$ and the hostile bid by International Specialty Products (ISP) for Dexter in December 1999 (in which Dexter sold itself to Invitrogen eight months later). ${ }^{157}$ The ITTHilton case was unique because the "clock" did not truly begin running until ITT's breakup defense had been invalidated by a federal district court in Nevada in October $1997 ;{ }^{158}$ as soon as it was, ITT found its white knight virtually immediately. And when resisting ISP, Dexter took longer than the typical target in finding a white knight but did so without the benefit of potent defenses: Dexter had a unitary (nonstaggered) board, and found its white knight just before its annual meeting, for which ISP was running an alternative full slate of directors. ${ }^{159}$ Therefore neither of these exceptions to the general trend provides support for the proposition that more potent defenses increase the likelihood of finding a higher-value white knight buyer. $^{160}$

To summarize, if fixed hostile bid costs, independent of the target's defenses, are larger than the width of the bargaining range, then a hostile bid is structurally precluded and the target's defenses are irrelevant for the takeover negotiation. If hostile bid costs are not monotonically increasing in the potency of the target's defenses, then baseline defenses may (or may not) give bargaining power, but more potent defenses do not necessarily give additional bargaining power. Only if both of these conditions do not hold is the bargaining power hypothesis valid at a theoretical level. The

155. See Bebchuk, Coates \& Subramanian, Hostile Bids Database, supra note 88.

156. See Christina Binkley et al., Araskog's Latest: To Elude Hilton, ITT Agrees To Be Acquired by a Real-Estate Trust, WALL ST. J., Oct. 21, 1997, at A1.

157. See Nikhil Deogun \& Scott Hensley, Invitrogen To Buy Dexter, Unit for \$1.9 Billion, WALL ST. J., July 10, 2000, at A15.

158. See Hilton Hotels Corp. v. ITT Corp., 978 F. Supp. 1342 (D. Nev. 1997).

159. See Deogun \& Hensley, supra note 157. Conversations with Samuel Heyman, Chairman of International Specialty Products, indicate that this deal may not have been an exception either: According to Mr. Heyman, Dexter may not have initially perceived the ISP proxy contest to be a serious threat; Dexter began looking only after the threat became clear, and found a white knight relatively quickly.

160. Admittedly, this analysis does not include targets that sold to the initial hostile bidder because they ran out of time to find a white knight. For an analysis of these targets, see supra note 131 . 
analysis therefore suggests that the bargaining power hypothesis operates in a smaller set of negotiated acquisitions than its proponents to date have argued.

\section{Asymmetric Information}

Even in situations where a hostile bid is not structurally precluded and hostile bid costs are increasing with the level of defenses, the majority of acquirers relinquish the hostile bid threat in a negotiated acquisition in order to gain access to the target's books and records. Donald Meltzer of Credit Suisse First Boston explains the acquirer's motivation:

I'm representing the buyer, and I look at it and say: "Am I really prepared to buy this company without due diligence?" And many times the answer is no.... Well, the price of getting due diligence is going to be the standstill agreement. And that standstill is going to provide as much or more protection than any of the normal defense mechanisms. ${ }^{161}$

In general, a "blind" bid (without the ability to conduct due diligence) is subject to the well-known "lemons problem," in which the bidder has possibly overpaid when the target accepts the offer. ${ }^{162}$ While one could imagine several potential solutions to this problem, ${ }^{163}$ the solution that has developed in the context of negotiated acquisitions is the standstill agreement. Surprisingly, despite their important implications for the interplay between negotiated and hostile acquisitions, standstill agreements have not received attention from modern academic commentators. ${ }^{164}$ Under

161. Meltzer Interview, supra note 108; see also Friedman Interview, supra note 107 ("The confidentiality agreement that exists in its standard form at every firm on the Street has a standstill paragraph in it."); Polle Interview, supra note 147 ("The other side, before they will give you access to do the due diligence, or typically before they will even agree to negotiate with you, will have you sign a confidentiality agreement that will include a standstill agreement.").

162. See George A. Akerlof, The Market for "Lemons": Quality Uncertainty and the Market Mechanism, 84 Q.J. ECON. 488 (1970); see also Schiller Interview, supra note 107 ("You'd much prefer getting confidential information, being able to kick the tires a bit, than having to do it from the outside.").

163. See, e.g., ROBERT H. MNOOKIN ET AL., BEYOND WINNING 25-27 (2000) (discussing methods for overcoming information asymmetries in negotiations).

164. Aside from technical discussions of standstill agreement mechanics in practitioneroriented publications, such as those of the Practicing Law Institute and the ALI-ABA, standstill agreements have been mentioned only in passing in the law review literature over the past ten years. Interestingly, standstill agreements received much greater attention from academic commentators when they first appeared in the early 1980s. See, e.g., Joseph W. Bartlett \& Christopher B. Andrews, The Standstill Agreement: Legal and Business Considerations Underlying a Corporate Peace Treaty, 62 B.U. L. REV. 143 (1982); Larry Y. Dann \& Harry DeAngelo, Standstill Agreements, Privately Negotiated Stock Repurchases, and the Market for Corporate Control, 11 J. FIN. ECON. 275 (1983); Steven A. Baronoff, Note, The Standstill 
the terms of a standstill, the potential acquirer agrees not to increase its stake in the target, conduct a proxy contest to replace the target's board, or make a tender offer for the target's stock without the approval of the target board, for a specified period of time, typically between six and twelve months. ${ }^{165}$ In exchange, the acquirer gains access to the target's internal documents, which allow it to conduct due diligence. Steve Wolitzer, Global Head of Mergers \& Acquisitions at Lehman Brothers, describes the reasoning that leads to a standstill:

One of the key issues is that we're going to share a lot of information with you. It's inside, nonpublic information. A lot of it may be very detailed, line-by-line. ... Why should we have all of these discussions, and you just turn around and make a hostile tender for me? If you do, I feel like a real chump, because I've given you all this information, and then you say, "Never mind, I'll just take my offer directly to your shareholders." So on the target side you say, "If you want to talk about a real merger, then sign a standstill and tell me you're not going to do anything unfriendly." That's the cost of entry. Otherwise, you're telling me you're not friendly. ${ }^{166}$

The exceptions demonstrate how common standstills are, as described by Stephen Munger at Morgan Stanley:

There are a few companies that say, "Look, we don't sign these things, period. We just don't do it." And the seller's banker sits there and says, "That's actually true-I've never seen these guys sign one." But only a handful of companies take that posture, and obviously you can only do it if you've historically had that posture. As you might expect, the companies that can get away with that are the bigger gorillas in the jungle. ${ }^{167}$

Agreement: A Case of Illegal Vote Selling and a Breach of Fiduciary Duty, 93 YALE L.J. 1093 (1984).

165. See Polle Interview, supra note 147 ("Six months would be a common shorter standstill."); Wolitzer Interview, supra note 135 ("Most of the standstills are for twelve months. We'll resist a standstill that is more than twelve months. A lot of that is on the theory that the information grows old.").

166. Wolitzer Interview, supra note 135; see also Munger Interview, supra note 88 ("Often what a target will do is say, 'Well, you want due diligence, the only way you're going to get it is if you sign this piece of paper saying you're not going to jump ugly with us."'); Schiller Interview, supra note 107 ("I approach you and want to buy your company. The first thing you are going to say is that you want a proper confidentiality agreement and a standstill.... Any big M\&A law firm is going to put a standstill in. It's sort of odd to call up and then not be willing to sign a standstill. It's good corporate practice on the sell side to demand it.").

167. Munger Interview, supra note 88; see also Alliance Gaming Corp. v. Bally Gaming Int'l, Inc., Civ. A. No. 14440, 1995 WL 523543, at *3 (Del. Ch. Aug. 11, 1995) ("The practice of requiring a bidder to sign a confidentiality and standstill agreement as a condition to allowing 
The standard practice of standstill agreements in negotiated acquisitions suggests two different tracks for acquiring a company. The first track is based on publicly available information, does not involve discussions with target management beyond an initial check (frequently in the form of a "bear hug" letter ${ }^{168}$ ), and goes directly to shareholders. ${ }^{169}$ The second track requires confidential information, invariably includes a standstill agreement, and involves intense negotiations between target and acquirer. ${ }^{170}$ Practitioners indicate that the decision as to which track to pursue is typically made early on. ${ }^{171}$ Louis Friedman, Global Head of Mergers \& Acquisitions at Bear Stearns, states:

\footnotetext{
'due diligence' access to confidential information, is well-recognized and accepted."); In re J.P. Stevens \& Co. S'holders Litig., 542 A.2d 770 (Del. Ch. 1988) (rejecting the claim that a target board's insistence on a particular form of standstill agreement constituted a breach of fiduciary duty); Marla A. Hoehn, Letters of Intent, Confidentiality and Standstill Agreements, in DRAFTING CORPORATE AGREEMENTS 2002-2003, at 69, 76 (PLI Corp. Law \& Practice Course, Handbook Series No. B0-01K0, 2002) ("[S]tandstill agreements are often included as provisions in a LOI [letter of intent]."). Because standstill agreements are not usually disclosed in the merger agreement, it is difficult to determine more systematically how common they are. Compare In re Pennaco Energy, Inc., 787 A.2d 691, 698 (Del. Ch. 2001) (describing a two-year standstill agreement included as part of a confidentiality agreement signed by Marathon Oil), with Schedule $14 \mathrm{C}$ Information Statement Furnished to the SEC by Pennaco Energy, Inc., supra note 59, at 3 (describing a confidentiality agreement signed by Marathon Oil on November 15, 2000, but not the accompanying standstill). One recent practitioner commentary states that the standard confidentiality agreement, even without an explicit standstill provision, still provides some protection against a hostile bid:
}

[A] confidentiality agreement without a standstill affords some protection to the target because the "permitted use" of information will not include using information to make a hostile acquisition. Nevertheless, this does not diminish the utility of a standstill because, from an evidentiary point of view, demonstrating a violation of a standstill agreement will be less burdensome than demonstrating that a buyer has misused confidential information.

Meryl S. Rosenblatt, Letters of Intent and Exclusivity, Confidentiality and Standstill Agreements, in DRAFTING CORPORATE AGREEMENTS 2002-2003, supra, at 95, 117. This analysis suggests that, in effect, standstills are even more common than the contract terms would indicate.

168. A bear hug is an unsolicited takeover offer that is not accompanied by either a tender offer or proxy contest.

169. See, e.g., Neissa Interview, supra note 136 ("If you're talking hostile, there really isn't negotiation as you would think of arms-length negotiation. Ninety-something percent of the time, there is no negotiation in a hostile. .. By definition, if there is going to be serious negotiation, you've taken the hostility out of it."); see also Mangalindan et al., supra note 144 ("Craig Conway, the [PeopleSoft] chief executive, says he was caught completely unaware during a business trip to Amsterdam when he was told of press reports about a $\$ 5.1$ billion hostile takeover offer from rival Oracle Corp."); Hall, Rose \& Subramanian, supra note 139, at 4 ("“I was rather stunned,' said [Circon CEO Richard] Auhll. 'I guess it became clear that it was going to be a hostile attempt. He didn't make any friendly overtures at all.'”).

170. The existence of standstill agreements and two tracks for acquiring a company call into question earlier work describing a continuum between negotiated acquisitions and hostile takeovers. See, e.g., Schwert, supra note 146, at 2600 ("Many transactions that seem hostile initially result in friendly negotiated settlements.").

171. See, e.g., Meltzer Interview, supra note 108 ("You frequently need to make the decision that affects whether you are going to be able to go unsolicited relatively early on in the process. ... Essentially you end up with a friendly path and an unfriendly path, and a fork in the road relatively early on."). 
When a potential seller puts forward a standstill agreement, then as a potential acquirer you have one of two choices. First, you could preserve your flexibility to pursue a hostile deal, in which case you do not move forward with the bilateral discussions because the target is not willing to share confidential information with you unless you agree to the standstill. Alternatively, you try to modify the standstill as much as you can, but fundamentally give up the basic ability to launch an unsolicited offer.... If the target is insisting on the standstill, you have to make the tactical decision right away, so you are not going to be able to hold it in reserve for a later threat. ${ }^{172}$

Therefore, if the standstill agreement is the standard quid pro quo for access to confidential books and records, and most acquirers in negotiated acquisitions agree to a standstill as standard business practice, then takeover defenses are irrelevant in determining the final price received by target shareholders in most negotiated acquisitions. ${ }^{173}$

\section{E. Agency Costs}

Finally, consider a situation in which the bargaining range is large (i.e., alternatives away from the table are weak), hostile bid costs are smaller than the width of the bargaining range, and the acquirer has not relinquished the hostile bid threat through a standstill agreement. Even in this case, it is not clear that takeover defenses will increase premiums for shareholders once the possibility of agency costs is introduced. If the target board is not a loyal agent for its shareholders, then it might use bargaining power provided by takeover defenses not to improve the premium that the target shareholders receive, but rather to extract private benefits. ${ }^{174}$

A simple quantitative example illustrates the point. Starting with the same assumptions as in the baseline model, consider a situation with complete defenses, in which two possible deals emerge from the negotiations between the target board and the acquirer: Deal $\mathrm{A}$ is a straightforward $\$ 110$ for the company; Deal B is $\$ 101$ for the company and

172. Friedman Interview, supra note 107.

173. See Schiller Interview, supra note 107 ("In a negotiated deal I don't believe that a staggered board and a pill really come in to play, because most of the time there is going to be some kind of standstill arrangement."). Nevertheless, I cannot rule out the possibility that the decision whether to sign a standstill agreement is influenced by the target's defenses. The theoretical prediction on this influence is ambiguous, because precisely when the standstill is cheap to give (i.e., when the target has strong defenses) it is less valuable for the target to receive. Unfortunately, assessing this sensitivity empirically is difficult for the reasons noted above. See supra note 167. At the very least, this Essay identifies the mechanism by which defenses must influence bargaining power in negotiated acquisitions. Contrary to current conventional wisdom, there is not a seamless continuum between friendly and hostile bids.

174. See Bebchuk, supra note 7, at 991. 
$\$ 5$ in value to target managers (e.g., through additional parachute provisions or positions in the continuing company that do not exist in Deal A). Because of the complete defenses assumption, the acquirer must get the target board's approval and cannot take either Deal A or Deal B directly to shareholders. A loyal target board would choose Deal A because it yields higher value for shareholders. But, of course, with the introduction of agency costs a target board might prefer Deal B. From the shareholders' perspective, Deal $B$ is no different from the scenario of a target with no defenses-in both cases the target shareholders receive $\$ 101$. The only difference is that Deal $\mathrm{B}$ provides private benefits to target managers. More value has in fact been extracted from the acquirer (consistent with the bargaining power hypothesis), but this value has not accrued to the benefit of shareholders (inconsistent with the hypothesis). ${ }^{175}$

Making matters worse is the fact that the acquirer also prefers Deal B because the total cost is lower: $\$ 106$ total cost ( $\$ 101$ to the shareholders and $\$ 5$ in private benefits) compared to $\$ 110$ in Deal A. In fact, any deal that provides a premium to target shareholders can be improved for both the acquirer and target managers by a deal that provides less value to the shareholders and gives some portion of that value to the target managers. The constituency that loses in this diversion of value is the target's shareholders, but in the regime of complete defenses posited above, these shareholders are not at the negotiating table. Thus, there are strong theoretical reasons to believe that agency costs might exist in the negotiation between the acquirer and the target board in a world of complete defenses.

Of course, fiduciary duty might limit the extent to which the target board can extract private benefits in the negotiation with the acquirer. Empirical evidence suggests, however, that the agency cost problem is present in many negotiated acquisitions. One study examines 252 friendly acquisitions from 1995 to 1997 and finds that CEOs who own less-than-average equity in their company (and who thus might have reduced incentives to maximize share price) are more likely to negotiate a lower premium for their shareholders if they receive an augmented golden parachute, additional merger-related payments (such as consulting contracts or special bonuses), a high position in the acquiring company, or a seat on the acquiring company's board. ${ }^{176}$ Another study finds that CEOs of target companies in "mergers of equals" are more likely to negotiate a lower

175. See also City Capital Assocs. v. Interco Inc., 551 A.2d 787, 798 (Del. Ch. 1988) (“[A]n active negotiator with power, in effect, to refuse the proposal may be able to extract a higher or otherwise more valuable proposal ...." (emphasis added)).

176. See Jay Hartzell et al., What's in It for Me? Personal Benefits Obtained by CEOs Whose Firms Are Acquired 20 (Mar. 2000) (unpublished manuscript, on file with author). 
premium for their shareholders. ${ }^{177}$ Both of these studies are consistent with the view that takeover defenses may result in private benefits for managers rather than higher premiums for shareholders. ${ }^{178}$

These studies and the quantitative example developed in this Section suggest that buyers may make use of the agency problem in crafting a deal with the target's managers. As described by Steve Wolitzer of Lehman Brothers,

The defenses say how you have to deal with them. ... If there is no role for the other CEO, you may have to pay a little more, because you're telling him that he has to disappear. If management has roles, you might be able to get a slightly cheaper price, because they will see the benefits of getting together. ${ }^{179}$

This reasoning suggests that the agency problem is fueled from the buy side. Another possibility is that buyers simply react to the incentives put in place by the target's managers and board:

If I see a company where the management is not under contract and they have no severance arrangements or no change-in-control payments, I envision a tougher battle because they are fighting for their lives. If I've seen that the board has actually given them a decent severance package, then the typical thing that happens is if you cut a reasonable deal, where they make enough money not to worry about their futures, they will make a deal. And I actually feel

177. See Julie Wulf, Do CEOs in Mergers Trade Power for Premium? Evidence from "Mergers of Equals" 29-30 (June 2002) (unpublished manuscript, on file with author). The author defines mergers of equals as transactions in which the target and acquirer have approximately the same pre-deal market capitalization and approximately the same post-deal board representation and shareholder ownership in the combined entity. See id. at 11.

178. Another, more obvious agency cost might be management's refusal to negotiate with the acquirer. See, e.g., Barbarians in the Valley, ECONOMIST, June 28, 2003, at 61, 61 (quoting PeopleSoft CEO Craig Conway as stating that he "could imagine no price nor combination of price and other conditions to recommend accepting [Oracle's] offer"); Steven Lipin et al., In Fight for Pennzoil, Old Suitor Becomes .the Pursued, WALL Sr. J., June 24, 1997, at B4 (quoting Letter from James L. Pate, Chairman and Chief Executive Officer, Pennzoil Co., to Jack Messman, Chief Executive Officer, Union Pacific Resources (May 1997) ("I thought I had made it plain that Pennzoil fully intends to remain independent and is not interested in engaging in any process that could put Pennzoil into play.")); Hall, Rose \& Subramanian, supra note 139, at 7 ("[Circon CEO] Auhll was instructed by legal counsel not to communicate with [U.S. Surgical CEO] Hirsch or other Surgical representatives, despite several attempts by Surgical to do so."). Although this phenomenon is inconsistent with the view that takeover defenses increase shareholder value, see supra Subsection II.C.2, it is not necessarily inconsistent with the bargaining power hypothesis, which is based on the premise that negotiations have already been initiated between acquirer and target.

179. Wolitzer Interview, supra note 135. 
more comfortable when that exists than less, in terms of being able to get to a deal. ${ }^{180}$

In either case, defenses might allow target managers to extract private benefits for themselves rather than a higher premium for shareholders.

\section{F. Synthesis}

Assessing the influence of the ESB defense, Wachtell, Lipton partner Mark Gordon states that

it seems an impossible feat of logic to argue, on the one hand, that ESBs present a "serious impediment to a hostile bidder seeking to gain control over the [incumbent directors'] objections" and are "extremely potent as an antitakeover device," while at the same time arguing that, on the other hand, boards are unable to use this extremely potent force to extract a better price from any genuinely interested suitor. ${ }^{181}$

In fact, it is entirely consistent to argue that takeover defenses are a potent weapon against a hostile takeover bid ${ }^{182}$ but are not important in most negotiated acquisitions. Far from being an "impossible feat of logic," I demonstrate that it is quite easy to hold this view once alternatives away from the table, hostile bid costs, asymmetric information, and agency costs are introduced into the standard bargaining model.

Practitioner interviews confirm this conclusion. The M\&A heads whom I interviewed (who actually negotiate price ${ }^{183}$ ) state that takeover defenses

180. $I d$.

181. Gordon, supra note 3, at 824 (quoting Bebchuk, Coates \& Subramanian, Powerful Antitakeover Force, supra note 6, at 890, 903) (alteration in original) (footnotes omitted).

182. See Bebchuk, Coates \& Subramanian, Powerful Antitakeover Force, supra note 6, at 937.

183. See, e.g., Meltzer Interview, supra note 108 ("Typically the commercial terms of the deal-meaning price, meaning what assets are we buying, what liabilities are we taking-that's usually a subject for the financial people to sort out."). Steve Wolitzer expressed similar sentiments:

The bankers will hash out the price and yell and scream at each other, and then very often the two CEOs will have a meeting and bridge the final gap, but that's always at the point where the CEOs can be the guys who make the deal, not the guys who break it. So a key part of the bankers' role is to make sure the hard negotiations are kept away from the key principals .... On a public-to-public deal, we will always advise that the advisors do the bulk of those kinds of negotiations.

Wolitzer Interview, supra note 135; see also JAMES C. FREUND, ANATOMY OF A MERGER 56 (1975) ("No legal mystique surrounds the subject of price, and the majority of businessmen are generally quite able to handle the matter on their own, without any intervention from the legal profession."). 
are relevant only in a subset of negotiated acquisitions. ${ }^{184}$ Michael Biondi of Lazard represented the median view:

In a negotiated deal, the existence or nonexistence of shark repellent stuff is generally not a big factor. Most of the time, the kind of deals that we are talking about aren't being done with some kind of veiled threat.... The assumption is that we like each other and are friendly to each other. There is often some sort of standstill provision in place, which generally takes you out of the land of worrying tremendously about what the structural defenses are. ${ }^{185}$

At the very least, the real-world factors identified here suggest that the bargaining power hypothesis cannot be accepted at the level of theory, but rather is an empirical question that must be tested against the available evidence. The next Part does so.

184. See, e.g., Braunstein Interview, supra note 88 ("Defenses are on one branch of the decision tree, but it's not a material branch of the decisionmaking process."); Meltzer Interview, supra note 108 ("I would say that in certain situations defenses matter, but probably not in most situations."); Munger Interview, supra note 88 ("Defenses are part of the picture, but probably a little bit to the side of the picture... My own personal view is that any effect of takeover defenses on aggregate shareholder wealth ... is within the noise of all the other variables that are out there."). Variations from this median view occurred in both directions. Compare Neissa Interview, supra note 136 ("I have never told a company that they should think that they should pay more [because of defenses]. I think some studies over the years have empirically said that that might be the case, but I don't think that thought has ever entered my mind-that I changed my view of fundamental economic value based on the defenses."), with Wolitzer Interview, supra note 135 ("[M]any acquirers do not seek long protracted battles, ... [so it is] better to pay up a little in a friendly deal than wage war to save a couple of dollars, or even to walk away than overpay."). In support of this latter perspective, one interviewee stated: "The go-in hostile bid for a company with defenses is much higher than for a company without defenses. ... Almost by definition it would follow that friendly deals would have to be priced higher as well." (This interviewee's identity remains anonymous for reasons cited supra note 101.) In prior work, however, Bebchuk, Coates, and I found no evidence that hostile bids against companies with defenses are priced higher than hostile bids against companies without defenses. See Bebchuk, Coates \& Subramanian, Powerful Antitakeover Force, supra note 6, at 935-36.

185. Biondi Interview, supra note 135. Michael Biondi elaborated this point further:

We tend to look at a defenses profile on a "pro forma" basis, just to see what they have, trying to anticipate whether there will be issues arising from some of these things, even if they are purely mechanical issues about having to get a board waiver so a pill won't trigger-some of the things that fall into the "Good Housekeeping" side of the transaction. You might put a summary of that sort of stuff into the file, just because you've done it, but generally in this context you don't see that stuff circulated to the board. People just aren't focused on it.

Id.; see also Braunstein Interview, supra note 88 ("At the margin structural defenses don't carry the day when you have a compelling economic offer. You have to think about economics-is it a good economic decision to go a dollar higher-not, does a dollar more overcome the shareholder rights plan."). 


\section{ECONOMETRIC EVIDENCE}

This Part tests the hypothesis that more potent takeover defenses increase premiums for target shareholders. Section A presents results from an interstate test, using differences in the background corporate law among states. Section B presents results from an intrastate test, using the Maryland Unsolicited Takeovers Act of 1999 as the basis for a natural experiment. Section C discusses implications of these results for the current and longstanding debate about whether takeover defenses increase or decrease overall shareholder value.

\section{A. Interstate Test}

I use the background corporate law of California, Delaware, Georgia, Maryland, Pennsylvania, and Virginia, as described in Section II.A, to test the hypothesis that stronger defenses increase premiums for target shareholders in negotiated acquisitions. The null hypothesis is that premiums are the same for targets incorporated in these different states. If the bargaining power hypothesis is correct, then premiums should be higher in states that authorize the most potent pills (Georgia, Maryland, Pennsylvania, and Virginia) ${ }^{186}$ and lower in the state that provides the least statutory validation for pills (California) relative to Delaware, which takes a middle ground on the pill question. ${ }^{187}$

The test is well-specified for two reasons. First, because pills do not require a shareholder vote, all targets in dead hand or slow hand states have the ability to put in a complete defense at any point. While in theory a company could waive this right in its charter, to my knowledge no company has done so. Conversely, all California companies have a far more limited right to put in a pill during takeover negotiations, and no California board can unilaterally bolster its pill through charter or bylaws provisions. ${ }^{188}$ Thus the background corporate law is applicable to all companies in the relevant jurisdictions.

186. I group Maryland, which authorizes slow hand pills, with Pennsylvania, Georgia, and Virginia, which authorize the more potent dead hand pills, because the Maryland Unsolicited Takeovers Act of 1999, unlike any other state statute, allows Maryland boards to adopt an effective staggered board without shareholder authorization, even if the ESB is contrary to the corporation's charter. See MD. CODE ANN., CORPS. \& ASS'NS § 3-803 (1999 \& Supp. 2002). This provision goes further than any other state statute and arguably makes Maryland the most antitakeover jurisdiction in the country. See infra Section IV.B. In unreported regressions I exclude Maryland and obtain similar results.

187. See supra figure 1.

188. See supra text accompanying notes $41-42$. 
Second, because reincorporations require a shareholder vote, and because reincorporations were relatively rare during the $1990 \mathrm{~s},{ }^{189}$ the background corporate law for most public companies is relatively independent of firm-level characteristics that might also influence deal premiums. For example, the pill studies suffer from potentially serious endogeneity problems because poorly performing companies may be more likely to put in pills. ${ }^{190}$ Even the ESB defense, because it is implemented at the firm level, may be endogenous to other firm-level characteristics that influence premiums. ${ }^{191}$ In contrast, state-level antitakeover statutes can be taken as relatively exogenous to firm-level characteristics.

\section{Methodology}

I begin with a sample of all negotiated acquisitions of U.S. public company targets that were announced and completed between January 1990 and December 2002, as reported in Thomson Financial Company's mergers and acquisitions database. I exclude unsolicited and hostile tender offers, mergers of equals, stock repurchases, spin-off transactions, acquisitions out of bankruptcy, and purchases of less than a controlling interest in order to focus on the kinds of takeover negotiations to which the bargaining power hypothesis most clearly applies. I exclude transactions in which the target company has a controlling shareholder because a controlling shareholder is a complete takeover defense against a hostile bid. I exclude freeze-out transactions because the Delaware courts have imposed an additional set of procedural requirements on these negotiations that are not present in arms-length negotiations between outside acquirers and the target board. ${ }^{192}$ I exclude transactions in which the acquirer held five percent or more at the time the deal was announced because such toehold positions may give the acquirer bargaining power unrelated to the defenses of the target. I exclude deals of less than $\$ 50$ million in value because targets that are smaller than this size often have illiquid stock, thus making premium data unreliable. The final sample includes 1692 negotiated acquisitions.

Following the convention among pill premium studies, I calculate the final deal premium received by target shareholders relative to one day prior to deal announcement, one week prior to announcement, and four weeks

189. See Subramanian, supra note 16 , at 1821 tbl.1 (reporting 373 reincorporations among a sample of 7820 U.S. public companies during the 1990s). Moreover, reincorporations during the 1990 s do not seem to be predicted by observable firm financial performance measures such as Tobin's Q or return on assets, see id. at 1850 tbl.7, which might influence deal premiums.

190. See supra text accompanying note 85 .

191. See infra text accompanying notes $221-223$.

192. See Kahn v. Lynch Communication Sys., Inc., 638 A.2d 1110 (Del. 1994); Weinberger v. UOP, lnc., 457 A.2d 701 (Del. 1983). 
prior to announcement. Unlike many of the pill studies, I adjust the premium received for market movements between the three baseline dates and the announcement date, using the value-weighted index from the University of Chicago's Center for Research in Security Prices database. ${ }^{193}$

\section{Overall Results}

I calculate the average (mean) premium, adjusted for market movements during the period between the baseline date and the announcement date, according to the potency of the target's pill as provided by the background state corporate law. Figure 4 shows the results.

Figure 4. EFFECT OF PILl POTENCY ON PREMIUMS

[Low (Cal.) $[\mathrm{n}=109]$ DMedium (Del.) $[\mathrm{n}=1263]$ High (Pa., Md, Ga., Va.) $[\mathrm{n}=173]$

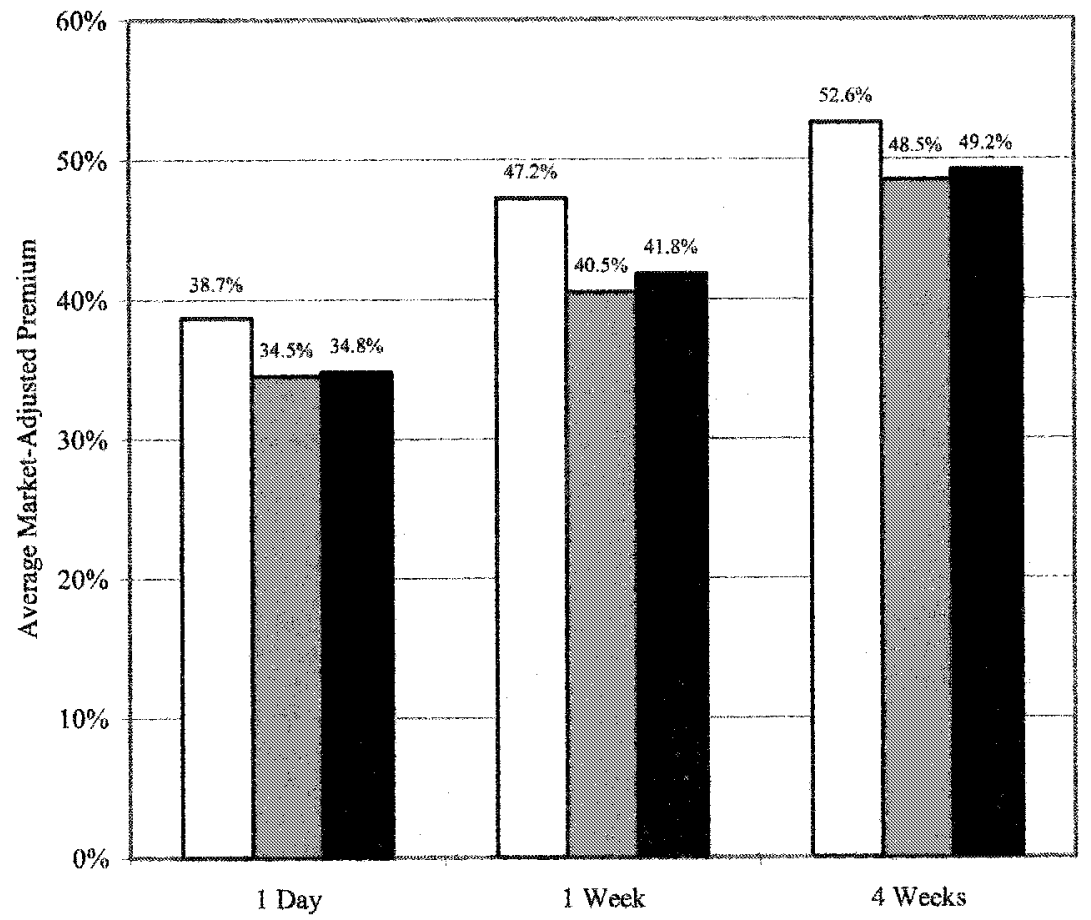

Baseline Date (Prior to Deal Announcement)

Figure 4 shows no statistically significant differences in the premiums received across these three types of jurisdictions. Target companies in

193. All findings reported in this Section (statistically significant and insignificant) continue to hold if I do not make this adjustment. 
states with the most potent defenses ${ }^{194}$ extract slightly higher premiums relative to Delaware, but the difference is not statistically significant or economically meaningful. In fact, the economically significant difference occurs between California and states with more potent pills, in a direction opposite to what the bargaining power hypothesis would predict: California targets, armed with the weakest pills, extracted premiums that were roughly five percent higher (not lower) than targets with more potent pills, though this result is also not statistically significant.

Of course, these univariate statistics may mask important differences across states that should be controlled for, to the extent possible, in order to isolate the effect of takeover defenses on premiums received. I therefore run a multivariate regression to control for other factors.

First, I control for the size of the deal by including log of deal size as an independent variable. Because the actual relationship between premium and deal size may not necessarily follow this particular functional form, I also include seven size dummy variables, with cutoffs at $\$ 100$ million, $\$ 250$ million, $\$ 500$ million, $\$ 1$ billion, $\$ 2.5$ billion, $\$ 5$ billion, and $\$ 10$ billion, and interactions between these dummy variables and $\log$ of deal size.

Second, I control for whether the acquirer provides a collar provision to the target, ${ }^{195}$ and whether the target provides the bidder with deal protection in the form of a breakup fee, stock option lockup, or topping fee. ${ }^{196}$ To the extent that these provisions are traded off against the deal price, one would expect to see a negative correlation between a collar agreement and deal premiums (because the target should pay to receive this insurance), and a positive correlation between deal protection and deal premiums (because the acquirer should pay to receive this insurance).

194. More specifically, Virginia targets are classified as having potent defenses after April 2, 1990, and Maryland targets are classified as having potent defenses after June 1, 1999, when their respective pill validation statutes became effective. See GRANT A. GARTMAN, STATE TAKEOVER LAWS, at Virginia-2, Maryland-2 to -3 (2000). Pennsylvania and Georgia targets are considered to have potent defenses throughout the sample period, because their pill validation statutes became effective on March 23, 1988, and February 7, 1989, respectively. See id. at Pennsylvania-4, Georgia-2. The one potentially problematic state is Georgia, where the validity of dead hand pills may have become clear only after the Invacare decision in July 1997. Invacare Corp. v. Healthdyne Techs., Inc., 968 F. Supp. 1578 (N.D. Ga. 1997). Results are similar if I classify Georgia targets as having potent defenses only after Invacare was decided.

195. A collar provision adjusts the exchange ratio or the price received by target shareholders in the event that the acquirer's stock price goes outside specified boundaries during the period between announcement and closing.

196. A breakup fee requires the target to pay the bidder a cash settlement in the event that one or more trigger conditions prevent the deal from being consummated. A stock option lockup gives the bidder the right to buy a specified percentage of the target's shares (typically 19.9\%) at a specified price (typically the deal price). A topping fee has the same payoff structure as a stock option lockup but involves cash rather than the issuance of additional shares. See Coates \& Subramanian, supra note 120 , at 314,365 n. 164 . 
Third, I control for the consideration received by target shareholders. Cash deals generally trigger tax recognition for target shareholders, while stock-for-stock deals are generally tax-free. Therefore, the acquirer may be expected to pay more in a cash deal than in a stock deal to offset partially the negative tax consequences for the target's shareholders, unless the target shareholders have losses rather than gains in their stock, or if a significant fraction of the shares are held by tax-exempt institutions.

Fourth, I include two dummy variables that attempt to control for potentially important elements of deal structure: whether a tender offer was made, and whether the deal was structured as a pooling of interests. ${ }^{197} \mathrm{~A}$ tender offer in particular may provide important deal insurance to the acquirer. In prior work, Professor Coates and I have shown that friendly deals executed through a first-stage tender offer are far more likely to close than deals that are executed through a merger agreement, perhaps due to the faster execution of a tender offer, which reduces the possibility of other bidders appearing. ${ }^{198}$ The acquirer should therefore be willing to pay for the additional insurance that a tender offer provides. ${ }^{199}$

Finally, I include industry dummy variables at the two-digit Standard Industrial Classification (SIC) code level to control for industry effects, and year dummy variables to control for potential time trends in premiums paid.

The dependent variable in all models is the market-adjusted premium received. The independent variable of interest is a categorical variable PILL, set to 0 if the target is incorporated in California (baseline), 1 if the target is incorporated in Delaware, and 2 if the target is incorporated in Georgia, Maryland, Pennsylvania, or Virginia. All models are run as robust regressions, which minimizes the influence of outliers relative to an ordinary least squares (OLS) regression model. Overall results are reported in Table 2.

197. A pooling-of-interests accounting method combines the two balance sheets with no additional goodwill created, which in turn avoids a drag on the acquirer's future earnings per share. In theory a buyer may be willing to pay more in order to get this favorable accounting treatment. The Financial Accounting Standards Board (FASB) eliminated pooling of interests as an accounting method for business combinations after June 30, 2001. See David M. Silk \& David A. Katz, Takeover Law and Practice 2003, in 2 DoING DEALS 2003, at 233, 327 (PLI Corp. Law \& Practice Course, Handbook Series No. B-1357, 2003).

198. See Coates \& Subramanian, supra note 120, at 351-53.

199. I thank Professor Coates for helpful conversations on this point. 


\section{TABle 2. EfFect of PILl Potency on Deal PREMIUMS}

\begin{tabular}{|c|c|c|c|}
\hline & 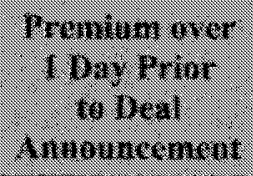 & 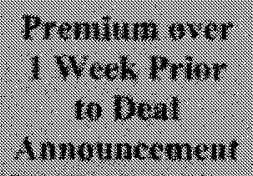 & 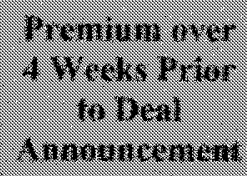 \\
\hline $\begin{array}{l}\text { Pill Potency: } \\
\text { Medium (Del) } \\
\text { High (Ca., Md., Pa., Va.) }\end{array}$ & $\begin{array}{r}-3.05(2.72) \\
-0.80(3.35) \\
\end{array}$ & $\begin{array}{l}-6.15(2.95)^{* * *} \\
-2.42(3.64)\end{array}$ & $\begin{array}{l}-4.40(3.46) \\
-3.47(4.26)\end{array}$ \\
\hline $\begin{array}{l}\text { Deal Characteristics: } \\
\text { Iog (market can) } \\
\text { An-cash } \\
\text { All-stock } \\
\text { Poolug-of-interests } \\
\text { tender offer }\end{array}$ & $\begin{array}{l}-0.76(7.61) \\
-0.10(2.69) \\
-0.06(2.70) \\
1.29(2.16) \\
6.52(1.97)^{* * * *}\end{array}$ & $\begin{array}{l}1.26(8.26) \\
0.20(2.92) \\
-1.47(2.92) \\
4.15(2.34)^{*} \\
10.27(2.13)^{* * *}\end{array}$ & $\begin{array}{l}2.38(9.69) \\
-1.12(3.44) \\
0.71(3.43) \\
0.61(2.74) \\
9.84(2.51)^{* * *}\end{array}$ \\
\hline 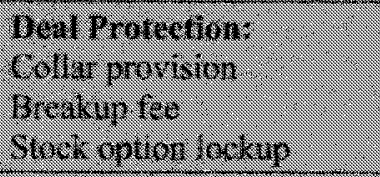 & $\begin{array}{l}-0.93(2.31) \\
1.69(1.71) \\
2.50(2.03) \\
\end{array}$ & $\begin{array}{l}-0.80(2.50) \\
1.47(1.86) \\
2.49(2.21) \\
\end{array}$ & $\begin{array}{l}1.57(2.94) \\
1.35(2.17) \\
1.17(2.58)\end{array}$ \\
\hline Observatenus: & 1544 & 1545 & 1548 \\
\hline
\end{tabular}

Notes: All models are run as robust regressions. Standard errors are reported in parentheses. All models include a constant term, industry controls (two-digit SIC code level), year controls, and interactions between size dummy variables and $\log$ of firm size (not reported). ${ }^{*}=$ statistically significant at $90 \%$ confidence; $* *$ statistically significant at $95 \%$ confidence; $* * *=$ statistically significant at $99 \%$ confidence.

Table 2 shows that most of the coefficients for the pill potency variables are statistically insignificant. The one coefficient that is statistically significant is in a direction opposite to what the bargaining power hypothesis would predict: Using premiums calculated over one week prior to deal announcement, Delaware targets, armed with moderate pills, achieve approximately six percent lower premiums than California targets, armed with weaker pills, even after controlling for industry differences that no doubt exist across these two states. ${ }^{200}$ While I can think of no reason why takeover defenses should reduce premiums in negotiated acquisitions, the results presented in Table 2 do not support the predictions of the bargaining power hypothesis.

Examining the control variables, Table 2 provides some mild support for the deal insurance hypothesis. Tender offers are highly correlated with higher deal premiums, consistent with the theory that buyers pay for the faster execution that a tender offer provides. The coefficients for breakup 
fees and stock option lockups are also consistently positive across models, consistent with the deal insurance hypothesis, but these coefficients are not statistically significant.

\section{Focused Samples}

Thus far I have tested the hypothesis that defenses provide a premium benefit across all deals and find no evidence to support this strong form of the bargaining power hypothesis. I now test the hypothesis that defenses increase premiums in particular kinds of deals. As suggested by the theoretical model put forward in Part III, I test two possibilities.

First, I test the hypothesis that defenses are effective in extracting higher premiums for targets with fixed assets, i.e., targets for which property, plant, and equipment rather than human capital are critical. The argument is twofold: first, that a hostile bid is more feasible against a target with hard assets, because the assets cannot readily exit; ${ }^{201}$ and second, that the bidder is less likely to relinquish the hostile bid threat against a hardassets target because the assets are easier to value without confidential information. I test this theory by running the baseline model only on targets in four SIC divisions: agriculture, forestry, and fishing (SIC codes 01-09); mining (10-14); construction (15-17); and manufacturing (20-39).

Second, the model presented in this Essay predicts that takeover defenses are more likely to be a binding constraint in a takeover negotiation if there are fewer alternatives away from the table for the bidder or the target. To test this theory, I run the model on deals announced after December 2000, when the M\&A slowdown began. ${ }^{202}$ A thinner M\&A marketplace suggests fewer walk-away alternatives, which in turn may increase the likelihood that defenses will give targets bargaining power against potential acquirers. As in Table 2, I run both models using baseline dates one day, one week, and four weeks prior to bid announcement. The dependent variable in all models is the market-adjusted premium received. The results are reported in Tables 3 and 4.

201. See Wolitzer Interview, supra note 135 ("[A hostile bid is viable] only in situations where hard assets are key, and where for whatever reason you think you can actually keep the employees. ... Otherwise you may lose more value than you can possibly gain.").

202. See Nikhil Deogun \& Kara Scannell, Market Swoon Stifles M\&A's Red-Hot Start, but Old Economy Supplies a Surprise Bounty, WALL ST. J., Jan. 2, 2001, at R4; Robin Sidel, Cash Is More Popular amid Drop in Mergers, WALL ST. J., Apr. 2, 2001, at C18. 


\section{TABle 3. EfFect of Pill Potency on Deal Premiums, FIXED-ASSET TARGETS ONLY}

\begin{tabular}{|c|c|c|c|}
\hline & 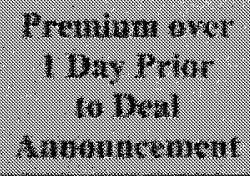 & 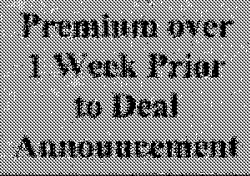 & 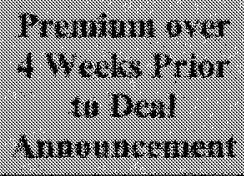 \\
\hline 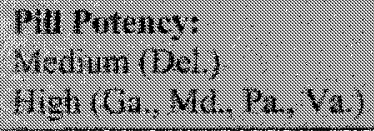 & $\begin{array}{l}-5.77(4.50) \\
-5.49(6.10)\end{array}$ & $\begin{array}{l}-8.93(4.83)^{*} \\
-4.10(6.54)\end{array}$ & $\begin{array}{l}-4.79(5.43) \\
-5.26(7.37)\end{array}$ \\
\hline 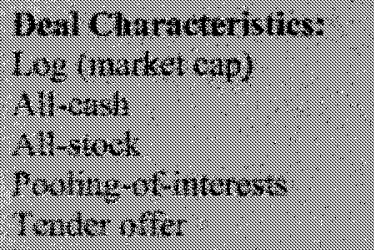 & $\begin{array}{l}7.38(9.07) \\
-5.32(4.73) \\
-1.80(4.80) \\
-1.84(3.83) \\
7.46(2.97)^{* * *}\end{array}$ & $\begin{array}{l}9.72(9.72) \\
-2.00(5.07) \\
-2.33(5.14) \\
2.78(4.10) \\
10.58(3.18)^{* * *}\end{array}$ & $\begin{array}{l}7.93(10.95) \\
-8.07(5.71) \\
-1.65(5.79) \\
-0.23(4.61) \\
12.37(3.58)^{*}\end{array}$ \\
\hline 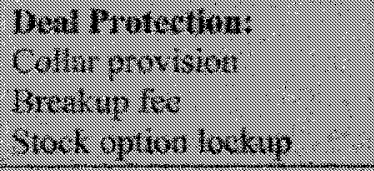 & $\begin{array}{l}-1.89(4.23) \\
6.16(2.96)^{*} \\
-2.23(3.80)\end{array}$ & $\begin{array}{l}-6.39(4.54) \\
5.18(3.17) \\
-2.58(4.07) \\
\end{array}$ & $\begin{array}{l}-4.00(5.11) \\
6.63(3.57)^{*} \\
-2.49(4.58)\end{array}$ \\
\hline 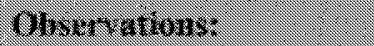 & 601 & 601 & 601 \\
\hline
\end{tabular}

Notes: All models are run as robust regressions. Standard errors are reported in parentheses. All models include a constant term, industry controls (two-digit SIC code level), year controls, and interactions between size dummy variables and $\log$ of firm size (not reported). ${ }^{*}=$ statistically significant at $90 \%$ confidence; $*$ = statistically significant at $95 \%$ confidence; $* * * *=$ statistically significant at $99 \%$ confidence.

The results reported in Tables 3 and 4 are consistent with the results reported in Table 2. The medium-potency coefficient continues to be weakly significant in some models, but in a direction that is inconsistent with the bargaining power hypothesis. Among controls, tender offers continue to be positively correlated with deal premiums, and statistically significant in some models; and the breakup fee coefficient is weakly significant in a positive direction for hard-asset targets, consistent with the deal insurance hypothesis. Overall, the coefficients for the pill potency variables in these more focused models do not support the bargaining power hypothesis. ${ }^{203}$

203. This conclusion does not change if I omit the medium-potency pill variable from the model and compare premiums in California and the high-potency pill states against a Delaware baseline. Against this baseline, the coefficients (standard errors) for high-potency pills in the second and third columns of Table 4 are $11.26(17.38)$ and $9.35(8.15)$, respectively. 
Table 4. Effect of Pill Potency on Deal Premiums, 2001-2002

\begin{tabular}{|c|c|c|c|}
\hline & 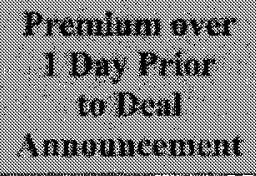 & 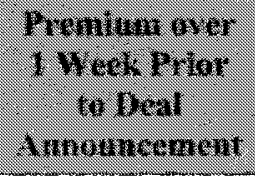 & 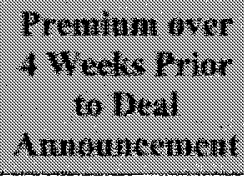 \\
\hline 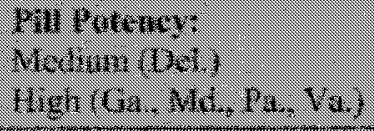 & $\begin{array}{l}-2.57(14.15) \\
5.19(14.64) \\
\end{array}$ & $\begin{array}{l}-13.97(17.38) \\
-2.71(18.02) \\
\end{array}$ & $\begin{array}{l}-32.24(18.38)^{*} \\
-22.89(19.06)\end{array}$ \\
\hline 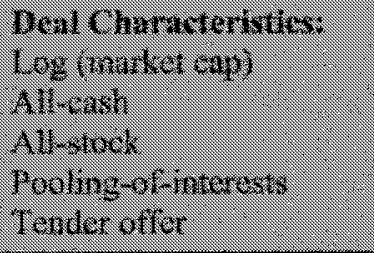 & $\begin{array}{l}1.58(23.03) \\
1.27(7.21) \\
0.92(7.09) \\
-1.09(14.52) \\
10.35(5.62)^{*}\end{array}$ & $\begin{array}{l}-0.52(28.39) \\
-3.31(8.88) \\
-0.24(8.74) \\
-21.23(17.89) \\
9.71(6.93)\end{array}$ & $\begin{array}{l}-8.09(30.03) \\
-6.07(9.39) \\
-4.96(9.24) \\
-34.61(18.92)^{*} \\
7.43(7.33)\end{array}$ \\
\hline 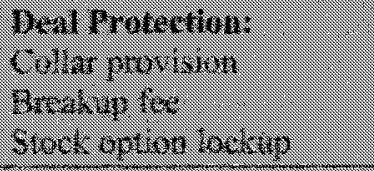 & $\begin{array}{l}-1.91(8.03) \\
5.20(6.10) \\
-6.96(8.76) \\
\end{array}$ & $\begin{array}{l}-1.92(9.89) \\
-11.01(7.48) \\
-4.36(10.79) \\
\end{array}$ & $\begin{array}{l}-9.21(10.46) \\
-9.83(7.91) \\
-3.43(11.41) \\
\end{array}$ \\
\hline Oheswatrons: & 225 & 229 & 229 \\
\hline
\end{tabular}

Notes: All models are run as robust regressions. Standard errors are reported in parentheses. All models include a constant term, industry controls (two-digit SIC code level), year controls, and interactions between size dummy variables and log of firm size (not reported). $*=$ statistically significant at $90 \%$ confidence; $* *=$ statistically significant at $95 \%$ confidence; $* * *=$ statistically significant at $99 \%$ confidence.

\section{B. Intrastate Test}

One concern with the econometric results presented in the previous Section is that there may be differences among firms incorporated in different states that are not adequately captured by industry and size controls. Most obviously, California has a disproportionate share of hightech companies, which may be fundamentally different from companies incorporated in other states. A partial response to this concern is the first focused sample presented in Subsection IV.A.3, which standardizes the set of industries under analysis. To provide a more complete response, I now present results from an intrastate test, using the Maryland Unsolicited Takeovers Act (MUTA) of 1999 as the basis for a natural experiment. MUTA became effective on June 1, 1999, and contains a broad array of potent takeover defenses: It endorses slow hand pills, as discussed in Section II.A; it rejects Delaware's heightened scrutiny for director conduct 
in sale-of-control situations; ${ }^{204}$ and it allows Maryland corporations to adopt an ESB without shareholder authorization, even if the ESB is contrary to the corporation's charter. ${ }^{205}$ These provisions make the Maryland statute one of the most potent antitakeover statutes in the United States, giving Maryland companies a close approximation to the "complete defense" that was theorized in Part III. If the bargaining power hypothesis is correct, then premiums for Maryland targets in negotiated acquisitions should increase after June 1, 1999.

Figure 5 presents average premiums for Maryland targets in negotiated acquisitions before and after MUTA went into effect.

FIGURE 5. PRE-AND POST-MUTA PREMIUMS

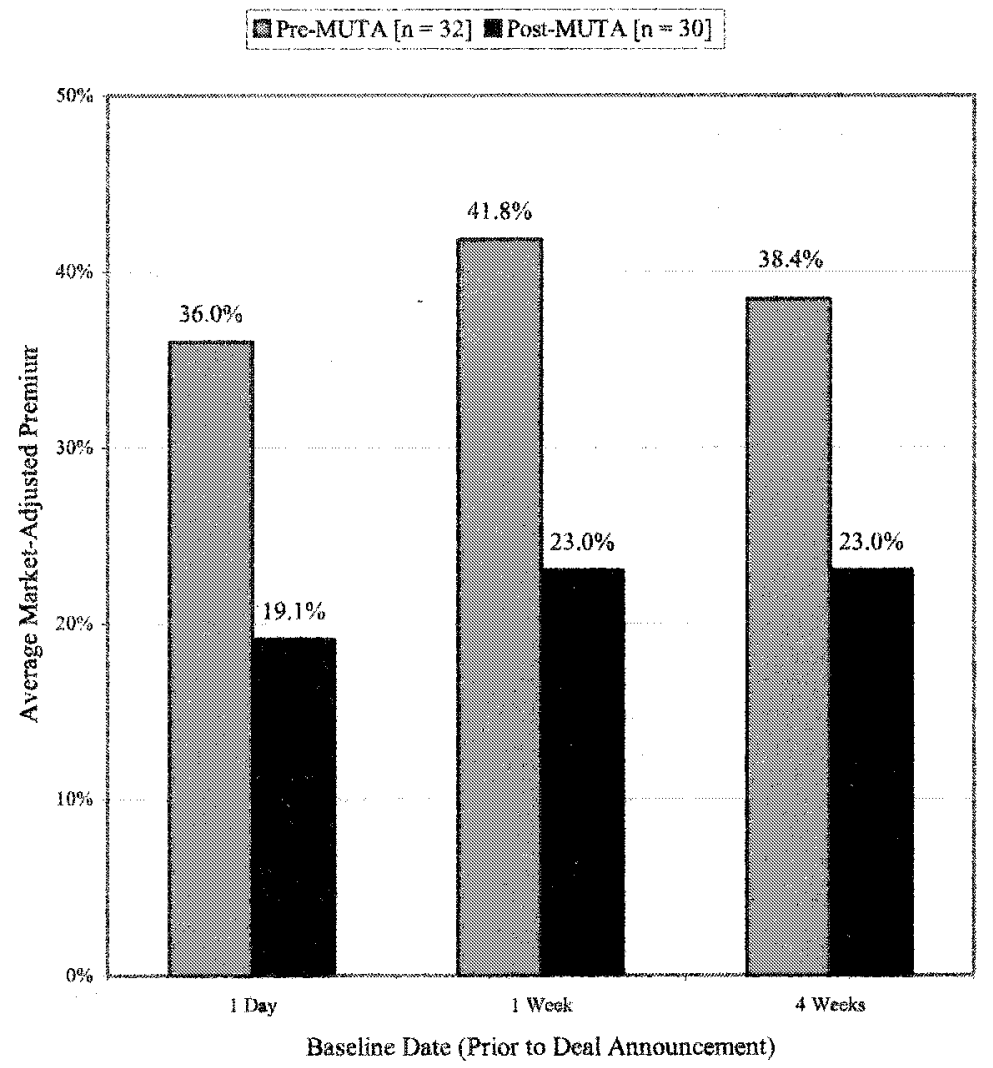

204. See Maryland Unsolicited Takeovers Act (MUTA) of 1999, MD. CODE ANN., CORPS. \& AsS'NS \& 2-405.1(d)(1), (f) (1999). In effect, this provision extends the "Just Say No" defense that Delaware courts have permitted for strategic, stock-for-stock mergers to all sale-of-control situations in Maryland.

205. See $i d . \$ 3-803$ (1999 \& Supp. 2002). Collateral provisions make the staggered board automatically effective. See id. $\$ \S 3-804(\mathrm{a})-(\mathrm{c}), 3-805(1)$. 
Although the sample size is small, Figure 5 shows a statistically significant decrease in premiums, at $90 \%$ confidence, after MUTA went into effect. This finding is consistent with the only statistically significant finding reported in Table 2, showing a negative coefficient for the pill potency variable in one specification.

As in the previous Section, I run a multivariate regression to control for other factors that might influence deal premiums. Because of the small number of observations, I use a subset of the controls included in Table 2. To control for a potential downward trend in premiums over the sample time period (and even though examination of the data does not reveal such a trend), ${ }^{206}$ I use as the dependent variable in each model the marketadjusted premium minus the average deal premium across all other states in the month that the deal is announced. ${ }^{207}$ The results are reported in Table 5.

\section{TABLE 5. EFFECT OF MUTA ON DEAL PREMIUMS}

\begin{tabular}{|c|c|c|c|}
\hline & 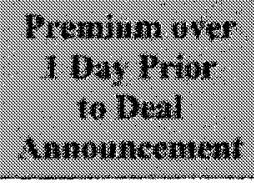 & 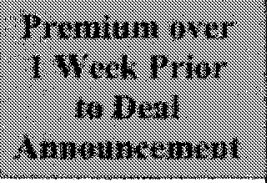 & 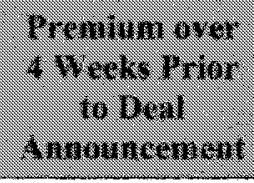 \\
\hline Jiters & $-12.18(5.44)^{* *}$ & $-14.68(4.97)^{* * *}$ & $-19.28(6.20)^{* * * *}$ \\
\hline 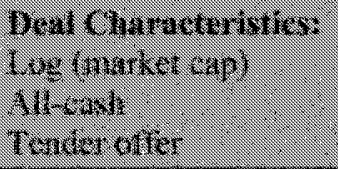 & $\begin{array}{l}0.22(1.80) \\
1.22(5.78) \\
9.24(6.55)\end{array}$ & $\begin{array}{l}0.07(1.65) \\
6.71(5.27) \\
17.64(5.98)^{* * *}\end{array}$ & $\begin{array}{l}0.54(2.05) \\
2.74(6.58) \\
17.76(7.46)^{* *}\end{array}$ \\
\hline $\begin{array}{l}\text { Deval Pratection: } \\
\text { Breakiup fer } \\
\text { Stock sprion locking }\end{array}$ & $\begin{array}{l}-5.35(5.18) \\
-4.16(7.24)\end{array}$ & $\begin{array}{l}-3.68(4.73) \\
6.64(6.61)\end{array}$ & $\begin{array}{l}-9.63(5.90) \\
13.54(8.24)\end{array}$ \\
\hline 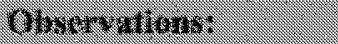 & 62 & 62 & 62 \\
\hline
\end{tabular}

Notes: All models are run as robust regressions. Standard errors are reported in parentheses. All models include a constant term. $*=$ statistically significant at $90 \%$ confidence; $* *=$ statistically significant at $95 \%$ confidence; $* * *$ statistically significant at $99 \%$ confidence.

Table 5 shows that the differences reported in Figure 5 continue to hold up in a statistically and economically significant way after controls for

206. Mean market-adjusted premiums for all other states during the pre-MUTA period are $31.7 \%$ relative to one day prior to bid announcement, $37.3 \%$ relative to one week prior to bid announcement, and $44.8 \%$ relative to four weeks prior to bid announcement. Mean market-adjusted premiums for all other states during the post-MUTA period are $37.1 \%, 43.9 \%$, and $52.2 \%$, respectively. These differences are not statistically significant; in fact, directionally, premiums in all other states went up rather than down after MUTA was enacted.

207. The findings reported in Table 5 (including the significance of the MUTA coefficient) continue to hold if $I$ use the market-adjusted premium without any time trend adjustment. 
other factors are introduced. Specifically, deal premiums in negotiated acquisitions were $12 \%$ to $19 \%$ lower after MUTA became effective, at $95 \%$ confidence in the first column and at $99 \%$ confidence in the next two columns. The results are the same when I eliminate premium outliers, which may have an undue impact in a small sample even though the model is run as a robust regression. The results are weaker but directionally similar when I eliminate real estate investment trusts (REITs) from the sample, ${ }^{208}$ which had uncertain vulnerability to hostile takeover during the period under consideration. ${ }^{209}$

Discussions with Maryland corporate lawyer James Hanks, one of the principal drafters of MUTA and author of the definitive treatise on Maryland corporate law, ${ }^{210}$ suggest no obvious causal connection between MUTA and decreased premiums for Maryland companies. ${ }^{211}$ Even in the absence of such a connection, however, it is clear that the Maryland evidence is inconsistent with the bargaining power hypothesis. More precisely, the findings presented in this Section reject the hypothesis, at ninety-five percent confidence, that MUTA led to higher premiums in negotiated acquisitions for Maryland companies.

\section{Assessment}

The empirical evidence presented in this Part is consistent with the theoretical model and practitioner evidence presented in Part III, suggesting that takeover defenses do not increase premiums in most negotiated acquisitions. This conclusion is consistent with several other empirical studies that also do not find evidence to support the bargaining power hypothesis. For example, Professors Robert Daines and Michael Klausner have found that the presence of takeover defenses at the IPO stage cannot be explained by the desire of IPO entrepreneurs to extract more in an

208. When I eliminate REITs, the MUTA coefficient continues to be negative in all regressions, but is only statistically significant at $95 \%$ confidence when I use deal premiums four weeks prior to announcement as the dependent variable. The weaker results may be due, at least in part, to the smaller number of observations in these models $(n=45)$.

209. While there have been several hostile bids against REITs in the modern era of takeovers, the vulnerability of REITs to hostile takeover bids became considerably clearer after Simon Property's hostile takeover bid for Taubman Centers Inc. (a REIT) in November 2002. See Dean Starkman \& Robin Sidel, Mall Brawl: Bid Marks REIT Turning Point, WALL ST. J., Apr. 28,2003 , at $\mathrm{Cl}$.

210. See JAMES J. HANKS, JR., MARYLAND CORPORATION LAW (2003).

211. See, e.g., E-mails from James J. Hanks, Jr., Partner, Venable LLP (Sept. 17-24, 2003) (on file with author). One potential explanation might be that bargaining power has already been impounded into the stock prices of Maryland companies. The magnitude of this effect would be the bargaining power benefit, multiplied by the likelihood of acquisition, and discounted by the expected time for the acquisition to occur. But because the likelihood of acquisition in any year was generally low even during the roaring 1990s M\&A market, the bulk of the bargaining power benefit should appear only in the takeover premium, when the company is acquired. 
eventual negotiated sale of the company. ${ }^{212}$ In follow-on work to our initial study of ESBs in the hostile takeover context, Bebchuk, Coates, and I reported no statistically significant difference in the premiums received by shareholders of thirty-nine ESB targets and thirty-four non-ESB targets. ${ }^{213}$ More generally, the evidence presented here is consistent with robust econometric evidence, reported in several studies over the past twenty years, demonstrating that share prices decrease when states pass antitakeover statutes. ${ }^{214}$ If the bargaining power hypothesis were correct, one would expect share prices to increase to reflect the greater premiums that would be extracted in future negotiated acquisitions. ${ }^{215}$

Finally, my theoretical model, practitioner interviews, and econometric evidence are consistent with revealed preference among shareholders in the 1990 s, who generally voted to rescind takeover defenses such as poison pills and staggered boards. ${ }^{216}$ If these defenses gave target boards bargaining power to extract higher premiums, one would expect shareholders to bestow these powerful weapons on their boards of directors rather than try to take them away. Or put differently, if the findings from the pill studies were correct, then shareholders in the 1990s attempted to destroy billions of dollars of (their own) value by passing precatory resolutions urging rescission of pills and staggered boards. Whatever rational apathy arguments might apply to shareholder decisionmaking on many corporate governance issues, the magnitude of the dollars at stake makes these arguments less likely to be valid with respect to the bargaining power hypothesis.

But despite the consistency of the evidence, the nature of the bargaining power hypothesis makes it difficult, as an econometric matter, to definitively disprove. ${ }^{217}$ This Essay nevertheless advances the debate by demonstrating that the bargaining power hypothesis cannot be accepted at the level of theory. The specific econometric question is whether the bargaining power benefit in some (potentially small) subset of negotiated

212. See Robert Daines \& Michael Klausner, Do IPO Charters Maximize Firm Value? Antitakeover Protection in IPOs, 17 J.L. ECON. \& ORG. 83, 85-86 (2001).

213. See Bebchuk, Coates \& Subramanian, Reply to Participants, supra note 6, at 906-07. Current efforts to expand this sample are consistent with this preliminary analysis.

214. For a review of studies from the 1980s and early 1990s, see ROBERTA ROMANO, THE GENIUS OF AMERICAN CORPORATE LAW 62 tbl.4-1 (1993). For a review of more recent studies, see GARTMAN, supra note 194, app. C.

215 . The countervailing cost of greater target bargaining power would be borne by acquirers, which are dispersed across all states.

216. See Michael Klausner, Institutional Shareholders, Private Equity, and Antitakeover Protection at the IPO Stage, 152 U. PA. L. REV. (forthcoming Dec. 2003) (manuscript at 2, on file with author).

217. Much in the same way as it would be difficult to disprove the hypothesis that the Boston Red Sox are more likely to win when I wear a blue shirt. We nevertheless reject this hypothesis at the level of theory. As Einstein noted, "It is the theory which decides what we can observe." See J. Bernstein, The Secret of the Old One, II, NEW YORKER, Mar. 17, 1973, at 44, 69. 
acquisitions is sufficient to offset the cost of strong defenses in the hostile deal context. Because the bargaining power hypothesis is not universally applicable to all negotiated acquisitions, it is not necessarily the case that "even a miniscule benefit" 218 in negotiated acquisitions is sufficient to offset the cost in the hostile bid context. In order to make the case that the net wealth effect of strong defenses is positive, one must examine both the benefit achieved and the scope of deals to which the benefit applies.

Even if future work were to find that stronger defenses were correlated with higher premiums, it would be unclear how to interpret the results. Because of the real-world factors introduced in Part III-most importantly, hostile bid costs and standstill agreements-there are strong theoretical reasons why higher premiums for strong-defense targets should not necessarily be attributed to the bargaining power hypothesis. Instead, two alternative explanations might provide a better explanation for such results.

First, there is the possibility that strong defenses deter low-premium bids (the "bid deterrence hypothesis"). Rather than simply shifting the distribution of deal premiums for strong-defense targets to the right (as the bargaining power hypothesis suggests), the distribution of deal premiums might be truncated at some number greater than zero because low-premium bids are unlikely to succeed. ${ }^{219}$ The two hypotheses are observationally equivalent-both would appear in the data as higher premiums for strong-defense targets-yet they have opposite welfare implications for target shareholders: If the bargaining power hypothesis is at work, then strong defenses increase target shareholder value, but if the bid deterrence hypothesis is at work, then strong defenses reduce target shareholder value because value-creating deals are deterred. ${ }^{220}$

A second possibility is that strong-defense targets are operationally weaker than weaker-defense targets (the "operational improvement hypothesis"). ${ }^{221}$ The causation might run in one of two ways: Either weaker companies put in strong defenses because the likelihood of a hostile

218. Kahan \& Rock, supra note 3 (manuscript at 23 ); see also Gordon, supra note 3 , at 824 (arguing that even a trivially small benefit in negotiated acquisitions would outweigh the cost of takeover defenses in the hostile bid arena).

219. See, e.g., Polle Interview, supra note 147 ("In more cases people walk away and they don't make the offer, because they think the offer will be rejected [when a target has strong defenses]."); see also Bebchuk, Coates \& Subramanian, Reply to Participants, supra note 6, at 907 n.70. I thank Professor Richard Zeckhauser for helpful conversations on this point.

220. See ROBERT CHARLES ClARK, CORPORATE LAW § 13.6 (1986) ("Shareholders as a group may be better off in the long run if the cost of takeovers is kept low and the number of takeovers high."); Easterbrook \& Fischel, supra note 150, at 1175. This analysis takes the perspective of target shareholders, which is the perspective that is most relevant for Delaware corporate law. From a social welfare perspective, however, bid deterrence unambiguously reduces shareholder value: Higher premiums merely transfer value from acquirer to target, and therefore can be ignored, leaving only the social cost of deterred deals.

221. This argument is more applicable to analyses of firm-level defenses than the state-level analyses presented here. See supra text accompanying notes 189-191. 
takeover bid is greater, or strong defenses permit larger managerial agency costs, which then reduce firm value. Regardless of which way the causation might run, one would expect higher premiums for strong-defense companies not because of greater bargaining power, but because of greater opportunity for operational improvements at these companies. ${ }^{222}$ This conclusion would be consistent with evidence offered by Professors Paul Gompers, Joy Ishii, and Andrew Metrick, showing that a portfolio of companies with few defenses outperformed a portfolio of companies with many defenses over the period 1990-1999. ${ }^{223}$

A methodology that would distinguish the bargaining power hypothesis from the operational improvement hypothesis (though not from the bid deterrence hypothesis) would involve examining the effect of the deal announcement on the acquirer's stock price in deals involving strongdefense targets and weaker-defense targets. If strong-defense targets are able to achieve higher premiums solely because of enhanced bargaining power, then acquirers should suffer a negative wealth effect, on average, in buying such targets relative to buying weaker-defense targets, because the greater value being extracted by the target would be taken out of the acquirer's stock price. Clearly this approach introduces challenges of its own; perhaps because of these challenges, such an approach has not been attempted to date. But because it is the only test that I know of that would rule out the operational improvement hypothesis in favor of bargaining power, it would seem to be an essential piece of the empirical evidence for the pro-defenses position.

\section{DISCUSSION}

The Delaware Supreme Court has made dramatic pro-shareholder moves over the past year: In every case involving directors' fiduciary duties since June 2002, when Congress passed the Sarbanes-Oxley Act, the court has ruled against management and in favor of shareholders, often expanding existing corporate law doctrines in important ways. ${ }^{224}$ In $M M$

222. Cf. Coates, supra note 15 , at 314 (making an analogous argument to explain the results of the pill studies).

223. See Paul Gompers et al., Corporate Governance and Equity Prices, 118 Q.J. ECON. 107 (2003).

224. See Thomas A. Roberts et al., Director Liability Warnings from Delaware, BUS. \& SEC. LITIGATOR, Feb. 2003, at 1, 12 (citing MM Cos. v. Liquid Audio, Inc., 813 A.2d 1118 (Del. 2003); Omni Care, Inc. v. NCS HealthCare, Inc., 822 A.2d 397 (Del. 2002) (unpublished table decision); Levco Alternative Fund Ltd. v. Reader's Digest Ass'n, 803 A.2d 428 (Del. 2002) (unpublished table decision); Saito v. McKesson HBOC, Inc., 806 A.2d 113 (Del. 2002); and Telxon Corp. v. Meyerson, 802 A.2d 257 (Del. 2002)); see also In re Walt Disney Co. Derivative Litig., 825 A.2d 275 (Del. Ch. 2003) (denying a motion to dismiss a complaint against the board of directors for breach of fiduciary duty in approving an employment agreement for Michael Ovitz). 
Cos. v. Liquid Audio, Inc., ${ }^{225}$ for example, the Delaware Supreme Court extended the stringent "compelling justification" standard articulated in Blasius Industries v. Atlas Corp. ${ }^{226}$ beyond actions that thwart the ability of a bidder to take control of the board, to include defensive measures that merely dilute the "substantial presence" of insurgent directors. ${ }^{227}$ Similarly, in a rare 3-2 decision, the court in Omni Care, Inc. v. NCS HealthCare, Inc. ${ }^{228}$ invalidated a shareholder lockup agreement as impermissibly preclusive, thus giving glimpses of what might run afoul of Unitrin's deferential restatement of Unocal's intermediate standard of review. One commentator described the Omni Care decision as " the most controversial corporate-law decision of the past 20 years.",229

This trend in Delaware jurisprudence is unlikely to be coincidental. As the SEC begins implementing the various provisions of the Sarbanes-Oxley Act, Delaware courts may have moved in a pro-shareholder, antimanagerial direction in order to avoid further federal preemption on (historically) state corporate law issues. ${ }^{230}$ Examining one hundred years of U.S. corporate law history, Professor Mark Roe finds a correlation between the threat of federal preemption and Delaware's corporate law jurisprudence. ${ }^{231}$ If this theory is correct, then Delaware may continue on this path, at least until the threat of federal preemption recedes.

This prediction is important for what it might mean for Delaware's takeover jurisprudence. If future takeover cases follow the general trend of the recent director fiduciary duty cases, then the Delaware courts may begin to replace what amounts to business judgment review of defensive tactics under Unitrin with a return to meaningful intermediate scrutiny review as originally articulated in Unocal -in effect, a return to Interco and the line of Delaware cases from the late 1980s in which courts engaged in substantive review of defensive tactics taken to thwart hostile takeover offers. ${ }^{232}$ Proponents of the status quo warn that this kind of doctrinal movement would weaken target boards' bargaining power in negotiated acquisitions, which would in turn reduce overall returns to target shareholders. But once the "black box" of negotiated acquisitions is

225. 813 A.2d 1118 .

226. 564 A.2d 651 (Del. Ch. 1988).

227. See Liquid Audio, 813 A.2d at 1132 ("As this case illustrates, such defensive actions ... need not actually prevent the shareholders from attaining any success in seating one or more nominees in a contested election for directors and the election contest need not involve a challenge for outright control of the board of directors.").

228. 822 A.2d 397.

229. Robin Sidel, Merger Business Faces New Order with Court Ruling on 'Lockups, 'WALL ST. J., Apr. 7, 2003, at C4 (quoting Professor Eric A. Chiappinelli of the Seattle University School of Law).

230. See Mark Roe, Delaware's Competition, 117 HARv. L. REv. 588, 643 (2003).

231. See id. (manuscript at 44-45).

232. See supra note 18 and accompanying text. 
unpacked, it becomes clear that the ability of potent takeover defenses to improve premiums for target shareholders in negotiated acquisitions is substantially limited.

In contrast, the upside of a revitalized takeover marketplace is potentially enormous. The experience of the past two years indicates there is no adequate substitute for a meaningful hostile takeover threat. Defenders of the antitakeover movement of the 1990s argue that the dramatic growth of stock option compensation ${ }^{233}$ and the increased representation of independent directors on corporate boards ${ }^{234}$ effectively offset the negative effects of entrenchment and higher agency costs. ${ }^{235}$ But putting aside the important question of whether stock options and independent directors were "adaptive devices"236 responding to the shutdown of hostile takeovers or were merely coincidental, this story is unsatisfying in two respects. First, the threat of a hostile takeover performs a unique disciplinary function that negotiated acquisitions do not. There is no reason to believe that the types of acquisitions that are motivated by stock option compensation, for example, will provide the same disciplinary benefit as hostile takeovers provide. ${ }^{237}$

Second, the failures at Enron and other U.S. public companies illustrate the "dark side" of relying on stock option compensation to motivate managers and reduce agency costs. ${ }^{238}$ While stock options can certainly be structured in ways that promote a long-term outlook among managers, the stock options that were prevalent in the 1990s are now well-understood to have promoted short-term behavior at some companies that took advantage of market speculation to the detriment of long-term shareholder interests. Thus, the irony of our experience in the 1990s is that we are now back to where we started: Hostile takeovers promoted a short-term outlook, argued the old school defense proponents, so defenses were justified as a way of allowing managers to adopt a longer-term perspective; takeover defenses gave rise to stock options, argued the new school defense proponents, which (it turns out) promoted the same short-term perspective that we were concerned about in the first place.

233. See Brian J. Hall \& Jeffrey B. Liebman, Are CEOs Really Paid Like Bureaucrats?, 113 Q.J. ECON. 653, 654-55 (1998).

234. See Sanjai Bhagat \& Bernard Black, The Uncertain Relationship Between Board Composition and Firm Performance, 54 BUS. LAW. 921,945 (1999) (reporting a decline in the number of inside directors at the median firm in their sample, "due to changes since 1991 in the composition of a typical board").

235. See Marcel Kahan \& Edward B. Rock, How I Learned To Stop Worrying and Love the Pill: Adaptive Responses to Takeover Law, 69 U. CHI. L. REV. 871, 896-97 (2002).

236. Id. at 872 .

237. See Reinier Kraakman, The Best of All Possible Worlds (or Pretty Darn Close), 69 U. CHI. L. REV. 933, 936 (2002).

238. See William W. Bratton, Enron and the Dark Side of Shareholder Value, 76 TUL. L. REV. 1275, 1327-28 (2002). 
In short, stock options and independent directors do not provide an adequate substitute for the hostile takeover threat as a disciplinary device against disloyal or incompetent managers. While this argument was difficult for some to accept during the roaring 1990 s, the connection between the hostile takeover threat and well-managed companies is becoming more widely acknowledged after the corporate governance failures of the past two years. ${ }^{239}$ In fact, some commentators have argued that the recent failures can be attributed directly to the shutdown of the hostile takeover marketplace. ${ }^{240}$ While I do not go so far, I do believe that the Sarbanes-Oxley Act and other reforms must be complemented by a meaningful market for corporate control. ${ }^{241}$

\section{CONCLUSION}

For decades, academics have claimed that friendly acquisitions are negotiated in the shadow of a hostile takeover bid. Interviews with senior M\&A investment bankers, however, indicate that this is not the case in many negotiated acquisitions. This Essay constructs a model of bargaining in the shadow of takeover defenses that bridges this gap. The model begins with a specification of the bargaining process involving a bilateral monopoly between buyer and seller, no hostile bid costs, symmetric information, and loyal sell-side agents. In this stylized model, the academic conventional wisdom clearly holds.

This Essay then goes on to introduce four real-world factors: alternatives away from the table, hostile bid costs, asymmetric information, and agency costs. No one doubts that these factors exist. And once these factors are introduced, it becomes clear that only a fraction of friendly acquisitions are in fact negotiated in the shadow of a hostile takeover threat. This conclusion is consistent with the basic claim among M\&A practitioners as well as the econometric evidence presented in this Essay.

239. See, e.g., Barbarians in the Valley, supra note 178, at 61 ("The business culture of the $1990 \mathrm{~s}$ - defined, above all, by the consensual business matings that spawned the greatest merger boom in history-now looks too cozy.").

240. See, e.g., Herbert Grubel, Editorial, Regulators vs. Adam Smith, WALL ST. J., Oct. 3, 2002, at Al4 ("Throughout history... hostile takeovers were profitable because the board of directors installed by new owners would eliminate practices that caused share prices to be depressed. Thus, executives with excessive compensation are replaced, bonus and option plans adjusted and shady accounting and self-dealing eliminated."); Henry G. Manne, Editorial, Bring Back the Hostile Takeover, WALL ST. J., June 26, 2002, at A18 ("New scandals will continue until we bring back the most powerful market mechanism for displacing bad managers: hostile takeovers.").

241. In other work, Bebchuk, Coates, and I have put forward a specific proposal that would move in this direction. See Bebchuk, Coates \& Subramanian, Powerful Antitakeover Force, supra note 6 , at $944-48$ (proposing that, absent explicit shareholder authorization to the contrary, incumbents protected by an ESB who lose one election over an outstanding bid should generally not be allowed by courts to further block the bid by maintaining a pill). 
The model has implications for the bargaining power hypothesis, which some commentators have put forward to support takeover defenses. If all acquisitions are negotiated against a background hostile threat, then Delaware courts should give target boards broad discretion to install and maintain takeover defenses, in order to achieve bargaining power against potential acquirers. But this Essay explores the microlevel underpinnings of negotiated acquisitions to find that the hostile bid threat is in the distant background in many deals. As a result, the bargaining power benefits of takeover defenses in negotiated acquisitions recede, and the costs of takeover defenses in the hostile bid context come to the fore.

These costs may be greater in today's global economy than they ever have been in the past. In the new millennium, activist European Union regulators are seeking to impose what amounts to an open market for corporate control in the EU. ${ }^{242}$ If these efforts prove successful (and after more than twenty years of efforts they are looking increasingly likely to be) ${ }^{243}$ then U.S. competitiveness in the global marketplace may depend in part on a willingness to expose American managers to the same disciplinary forces. Doctrinally, the Delaware courts will need to determine whether and to what extent to roll back the sweeping deference that they have given corporate boards during the 1990s, in favor of Unocal's original promise of intermediate scrutiny. This Essay provides a theoretical model, practitioner interviews, and econometric evidence suggesting that such a move would not create a significant countervailing cost for target shareholders in the form of reduced bargaining power in negotiated acquisitions.

242. See John C. Coates IV, Ownership, Takeovers and EU Law: How Contestable Should EU Corporations Be? , in MODERN COMPANY AND TAKEOVER LAW IN EUROPE (Guido Ferrarini et al. eds., forthcoming 2003) (manuscript at 1-5), available at http://papers.ssm.com/sol3/ papers.cfm?abstract_id $=424720$.

243. See id. 


\section{APPENDIX: INTERVIEW GUIDE}

The following questions were sent to all interviewees in advance:

For all questions consider the case of widely-held U.S. public companies negotiating a merger or acquisition in the late 1990s/early 2000 s M\&A market:

1. Initiating negotiations: Is there a typical way in which the approach is made to assess interest? (CEO to CEO? through the bankers?) Is the approach different if it is initiated by the buyer or the seller? Are deals generally initiated by the buyer or the seller?

2. Negotiation process: Who negotiates the price term? (the bankers? the CEOs?) Who negotiates other terms, e.g., deal protection, social issues? How, if at all, do the lawyers (inside and outside counsel) influence the negotiation of these issues?

3. Influence of the target's takeover defenses: As an acquirer, do you consider the takeover defenses of the target in determining what price to offer? Under what circumstances do you get a takeover defense profile from your lawyer? Which takeover defenses matter in your view, if any? Specifically, what significance do you attach to the target having a poison pill?

4. Viability of a hostile bid: In a negotiated acquisition, how do you think about the possibility of a hostile bid-is it a meaningful weapon in a takeover negotiation? Have you threatened, explicitly or implicitly, to make a hostile bid in a negotiated acquisition? To what extent are standstill agreements commonplace in merger negotiations?

5. Walk-away alternatives: How important are walk-away alternatives in influencing the negotiation at the table-do you explicitly think them through before making an initial approach? Are there typically many feasible alternatives to a given deal?

6. Consideration offered: How is the negotiation different when you are negotiating a stock-for-stock deal versus a cash deal? How do you think about the possibility of other bidders in these two kinds of deals-is there a greater threat in a cash deal than in a stock deal? 